\title{
Synthesis of an innovative zirconia-mullite raw material sintered from andalusite and zircon precursors and an evaluation of its corrosion and thermal shock performance
}

\author{
M.L. Bouchetou, J. Poirier, CNRS, CEMHTI UPR 3079, Univ. Orléans, France \\ L. Arbelaez Morales, T. Chotard, CNRS, IRCER UMR 7315 Univ. Limoges, France \\ O. Joubert, Imerys Refractory Minerals, Paris, France \\ M.Weissenbacher, CARRD, Villach, Austria
}

\begin{abstract}
This paper deals with the synthesis and the properties of an innovative zirconia-mullite raw material sintered from an andalusite/alumina/zircon mix. The microstructure of these composite grains consists of fine zirconia particles in a mullite matrix. This study highlights that the synthesis process (sintering from $\mathrm{SiO}_{2} \cdot \mathrm{Al}_{2} \mathrm{O}_{3}, \mathrm{Al}_{2} \mathrm{O}_{3}$ and $\mathrm{ZrSiO}_{4}$ raw materials) plays an essential role in the improvement of both the corrosion resistance to alumina-lime slag and soda-lime glass and the thermal shock resistance of this refractory. The microstructural observations correlated with non-destructive characterizations, ultrasonic pulse echography and acoustic emission techniques, underline the repairing mechanism exhibited by this material after experiencing repeated thermal shock.
\end{abstract}

\section{Introduction}

Zirconia mullite composites are commonly used as a raw material in refractory products due to their excellent properties. Zirconia has a high refractoriness $\left(\mathrm{T}_{\text {melting }}=2715^{\circ} \mathrm{C}\right)$ and has an exceptional corrosion resistance against slags [1]. Many authors have studied zirconia mullite composites $[2,3,4]$ and have observed high toughness, high strength and an interesting thermal shock resistance $[5,6,7,8]$. Because of the properties imparted by zirconia grains, they are thought responsible for the enhanced mechanical properties. These composites are used in the production of iron, steel, non-ferrous metals, cement and glass, as well as for hazardous waste incineration.

However, in many cases, the desired operating life is not achieved when using zirconia mullite composites owing to their low thermal shock and corrosion resistances. In particular, the performance of conventional zirconia mullite refractories are insufficient in terms of the service life needs when used as a replacement for alumina chromium oxide refractories that 
give rise to severe environmental problems [9]. Furthermore, there is still a demand in the refractory industry for improved and environmentally safe mullite/zirconia raw material for refractory products.

The classical way to generate mullite/zirconia composites is by the reaction of alumina with zircon. This reaction is carried out at very high temperatures due to the thermodynamic stability of zircon. Commercial electro-fused zirconia mullite is produced through a fusion process by melting a mixture of $\mathrm{ZrSiO}_{4}$ and $\mathrm{Al}_{2} \mathrm{O}_{3}$ in an electric arc furnace. Commercial sintered zirconia mullite raw material is produced through a sintering process at very high temperatures.

Another possible source of mullite is andalusite. Andalusite is a well-known alumina-silicate mineral employed in the refractory industry to provide high thermal shock resistance and strong mechanical properties. Majidian et al. [10] determined that the addition of andalusite in an alumina-mullite-zirconia composite improves properties such as thermal shock resistance. The addition of well-dispersed zirconia grains also improves the corrosion resistance against slags and molten glasses [11].

The purpose of this paper is to present a cost-cutting and innovative raw material, formed at a lower temperature, with an improved corrosion and thermal shock resistance. This sintered zirconia mullite refractory composite is developed from andalusite $\left(\mathrm{SiO}_{2} \cdot \mathrm{Al}_{2} \mathrm{O}_{3}\right)$, alumina $\mathrm{Al}_{2} \mathrm{O}_{3}$ and $\mathrm{ZrSiO}_{4}$ raw materials. This paper is composed of three main parts. In the first part, the high-temperature transformations of andalusite and zircon as precursors of mullite and zirconia are studied. In the second part, the synthesis of a sintered zirconia mullite raw material and the reactions that occur during the sintering are described. In the third part, the properties of the sintered zirconia mullite composite are evaluated. The effect of corrosion by soda-lime glass and $\mathrm{Al}_{2} \mathrm{O}_{3}-\mathrm{CaO}$ slags on the microstructural transformation of the zirconia mullite composite is investigated. Finally, the characterization of the thermomechanical behaviour of the composite is conducted by studying the thermal shock behavior evaluated using non-destructive ultrasonic methods (pulse echography and acoustic emission) to follow the microstructural changes at high temperature.

\section{Materials and methods}

\subsection{Raw materials and synthesis}

The raw materials used as the precursors for the synthesis of the sintered zirconia mullite composite are fine powders of micronized KF andalusite (Imerys), zircon (Ceradel) and 
CT3000SG alumina (Alcoa). Their compositions and grain sizes are shown in Table 1.

These powders were mixed in water and the samples shaped by slip casting in a plaster mould. After drying, the samples were heated at $1600{ }^{\circ} \mathrm{C}$ in air, for ten hours, at the heating rate of $900{ }^{\circ} \mathrm{C} / \mathrm{h}$.

\begin{tabular}{|c|c|c|c|}
\hline & $\begin{array}{l}\text { Micronised KF andalusite } \\
\text { (Imerys) }\end{array}$ & $\begin{array}{l}\text { CT3000SG alumina } \\
\text { (Alcoa Chemie GmbH) }\end{array}$ & $\begin{array}{l}\text { Zircon } \\
\text { (Ceradel) }\end{array}$ \\
\hline \multicolumn{4}{|c|}{ Chemical composition (weight \%) } \\
\hline $\mathrm{Al}_{2} \mathrm{O}_{3}$ & 61.1 & 99.8 & 0.5 \\
\hline $\mathrm{SiO}_{2}$ & 37.8 & 0.03 & 34.1 \\
\hline $\mathrm{ZrO}_{2}+\mathrm{HfO}_{2}$ & & & 64.4 \\
\hline $\mathrm{CaO}$ & 0.04 & & \\
\hline $\mathrm{MgO}$ & 0.04 & 0.08 & \\
\hline $\mathrm{TiO}_{2}$ & 0.12 & & \\
\hline $\mathrm{Fe}_{2} \mathrm{O}_{3}$ & 0.44 & & 0.07 \\
\hline $\mathrm{Na}_{2} \mathrm{O}$ & 0.04 & 0.08 & \\
\hline $\mathrm{K}_{2} \mathrm{O}$ & 0.2 & & \\
\hline \multicolumn{4}{|l|}{ Particle size } \\
\hline D50 $(\mu \mathrm{m})$ & $5 \mu \mathrm{m}$ & 0.8 & 1.3 \\
\hline
\end{tabular}

Table 1. Chemical composition and particle size of raw materials

\subsection{Characterization methods}

Crystalline phases in the fired samples were determined by XRD analysis on ground powders (-325 mesh) analysed in a Bragg-Brentano diffractometer (D8 Advance, Bruker) using $\mathrm{Cu}_{\mathrm{K} \alpha}$ radiation. Quantitative analyses were performed using the Rietveld method. The microstructures of polished and carbon coated samples were examined with an optical microscope and a scanning electron microscope. Bulk density and apparent porosity were measured using the standard water immersion method (ISO 5017).

The corrosion resistance against molten alumina-lime slag and against soda-lime glass was evaluated. The glass and slag compositions are given in Table 2.

\begin{tabular}{|c|c|c|c|c|c|}
\hline Weight \% & $\mathbf{A l}_{2} \mathbf{O}_{3}$ & $\mathbf{S i O}_{2}$ & $\mathbf{N a}_{2} \mathbf{O}$ & $\mathbf{C a O}$ & $\mathbf{M g O}$ \\
\hline Soda-lime glass & 0 & 71.6 & 14.2 & 9.5 & 4.7 \\
\hline $\mathrm{Al}_{2} \mathrm{O}_{3}-\mathrm{CaO}$ slag & 50 & 0 & 0 & 50 & 0 \\
\hline
\end{tabular}

Table 2. Composition of the corrosive agents (glass and slag)

The corrosion test was conducted in alumina crucibles filled with grains of the zirconia mullite samples and covered with the pressed fine powder of the slag or glass corrosive agent 
(Fig. 1). After corrosion, the depth of diffusion of the calcium in the grains was measured for every sample with a scanning electron microscope.

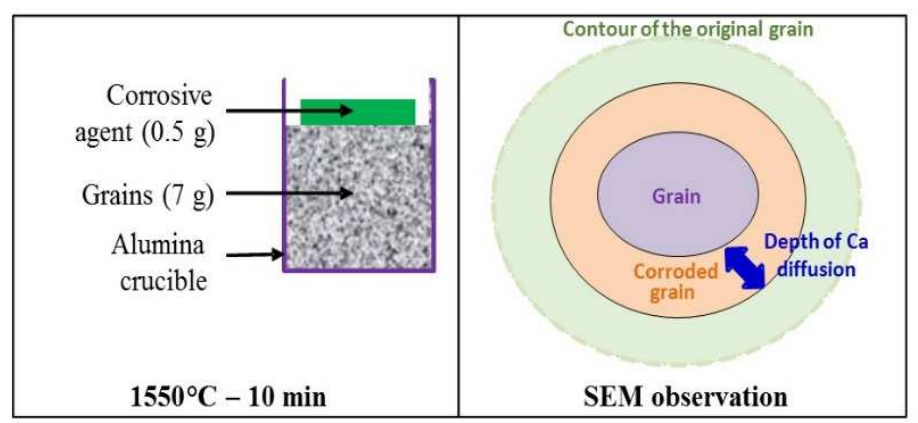

Fig. 1. Corrosion test and determination of Ca diffusion

The zirconia-mullite material, sintered at $1600{ }^{\circ} \mathrm{C}$ from andalusite, alumina and zircon powders, was first thermally shocked by heating the samples to $1200{ }^{\circ} \mathrm{C}$ for two hours and subsequently cooling to room temperature. The heating rate and the cooling rate, measured with thermocouples, were $300{ }^{\circ} \mathrm{C} / \mathrm{h}$ and $220{ }^{\circ} \mathrm{C} / \mathrm{min}$. The dimensions of samples were: $10 \mathrm{~mm}$ thickness, $15 \mathrm{~mm}$ width and $40 \mathrm{~mm}$ length.

The effect of the thermal shock on residual mechanical performances (evolution of elastic properties) was evaluated using a classical ultrasonic pulse echography technique in transmission mode.

No standard test can provide reliable results because of the great variety of microstructures to be tested and due to the necessary optimisation of the testing parameters (transmission or reflection mode, working frequency).

The ultrasonic wave propagation velocity was measured using a Sofranel EPOCH system and M106 (2 MHz) sensors. The reflection method could not be applied here due to the significant acoustic absorbance of the composite. The evolution of the ultrasonic pression wave velocity, which depends on several parameters (mineralogical phases, porosity, crack networks, and chemical composition), was studied to estimate the resistance of the material after experiencing several repeated thermal shocks (a maximum of 5). It is important to note that the variation in the elastic properties (the modulus of elasticity E, the Coulomb's modulus $\mathrm{G}$ and the Poison's ratio v) are not given in this publication, but the evolution of the porosity and relative density of the material will be presented and discussed in a future work. In the present paper, the analysis of the wave velocity variation is semi-quantitative. 
The thermomechanical behaviour of the sintered zirconia/mullite refractory composite was also studied using the acoustic emission (AE) technique at high temperature. The samples were prepared with standard machining tools and had dimensions of $25 \mathrm{~mm} \times 4 \mathrm{~mm} \times 4 \mathrm{~mm}$. The AE technique is devoted to the in-situ investigation and characterization of microstructure evolution when submitted to stress (mechanical, thermal, etc.). In the case of solid materials, microstructural changes such as dislocation slip, plastic deformation of grains, grain boundary sliding, and crack formation and propagation are sources of elastic waves $[12,13,14]$. Reference [15] described the experimental procedure applied in this research and for different types of material. The rapid releases of energy phenomena are detected and recorded in real-time and through established chronology of events (occurrence of signals coming with time from the tested material), phenomena which become very helpful to characterize and identify the involved mechanisms (Fig. 2). A PAC Micro-80 SN AB21 wideband sensor (200 to $900 \mathrm{kHz}-$ Mistras Group, Inc., USA) was used to perform this test. The threshold was set at $40 \mathrm{~dB}$ to avoid any background noise. The acoustic signals were acquired by an AE Express-8 system and the data were processed using the NOESIS software.

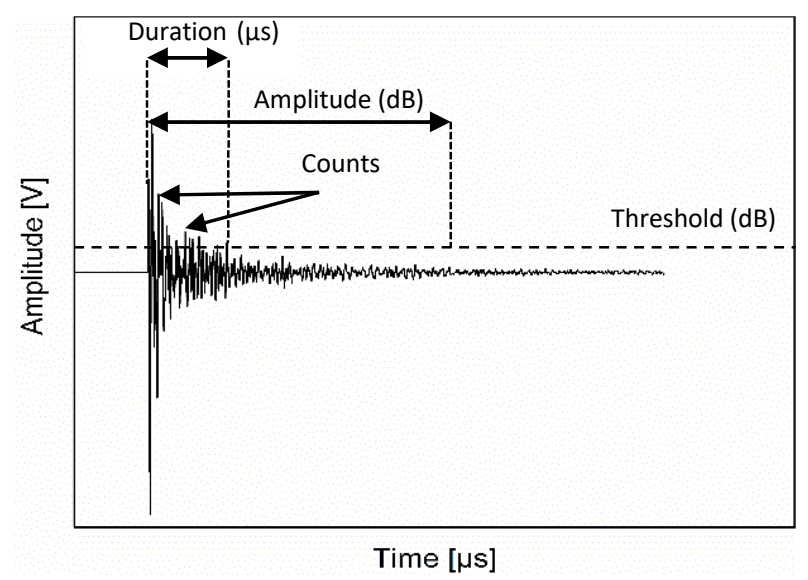

Fig. 2. Typical AE signal with recorded parameters

\section{Synthesis of the sintered zirconia mullite raw material}

Commercial fused and sintered zirconia mullite refractory raw materials, industrially produced from zircon $\left(\mathrm{ZrSiO}_{4}\right)$ and alumina $\left(\mathrm{Al}_{2} \mathrm{O}_{3}\right)$, are generated at very high temperatures with a high production cost. For example, the chemical compositions and the microstructures of two commercial zirconia mullite raw materials (Z 72 Symulox® - Nabeltec and FZM Imerys) are given Table 3, and their microstructures are shown in the Fig.3 and Fig.4. The electro-fused zirconia mullite refractory raw material (Z 72 Symulox ${ }^{\circledR}$ - Nabeltec) comprised 
a mineral phase consisting mainly of crystalline zirconia $\left(\mathrm{ZrO}_{2}\right)$ and mullite $\left(2 \mathrm{SiO}_{2} \cdot 3 \mathrm{Al}_{2} \mathrm{O}_{3}\right)$, with coarse zirconia crystal grains dispersed in the mullite matrix. An additional glassy phase was also present in the zirconia mullite raw material. The commercial sintered zirconia mullite raw material (FZM -Imerys) comprised fine crystalline zirconia grains dispersed in a mullitic matrix with little residual amorphous phase.

\begin{tabular}{|c|c|c|}
\hline Raw material & Sintered zirconia mullite & Fused zirconia mullite \\
\hline Product & $\begin{array}{c}\mathrm{Z} 72 \text { Symulox } \\
\text { Nabeltec }\end{array}$ & $\begin{array}{c}\text { FZM } \\
\text { Imerys }\end{array}$ \\
\hline \multicolumn{2}{|c|}{ Chemical composition (weight \%) } \\
\hline $\mathrm{Al}_{2} \mathrm{O}_{3}$ & 45 & 45.8 \\
\hline $\mathrm{SiO}_{2}$ & 19 & 17.1 \\
\hline $\mathrm{ZrO}_{2}+\mathrm{HfO}_{2}$ & 35 & 36.5 \\
\hline $\mathrm{CaO}$ & 0.05 & 0.1 \\
\hline $\mathrm{MgO}$ & 0.05 & - \\
\hline $\mathrm{TiO}_{2}$ & 0.1 & 0.1 \\
\hline $\mathrm{Fe}_{2} \mathrm{O}_{3}$ & 0.1 & 0.1 \\
\hline
\end{tabular}

Table 3. Chemical composition of two commercial zirconia mullite raw materials

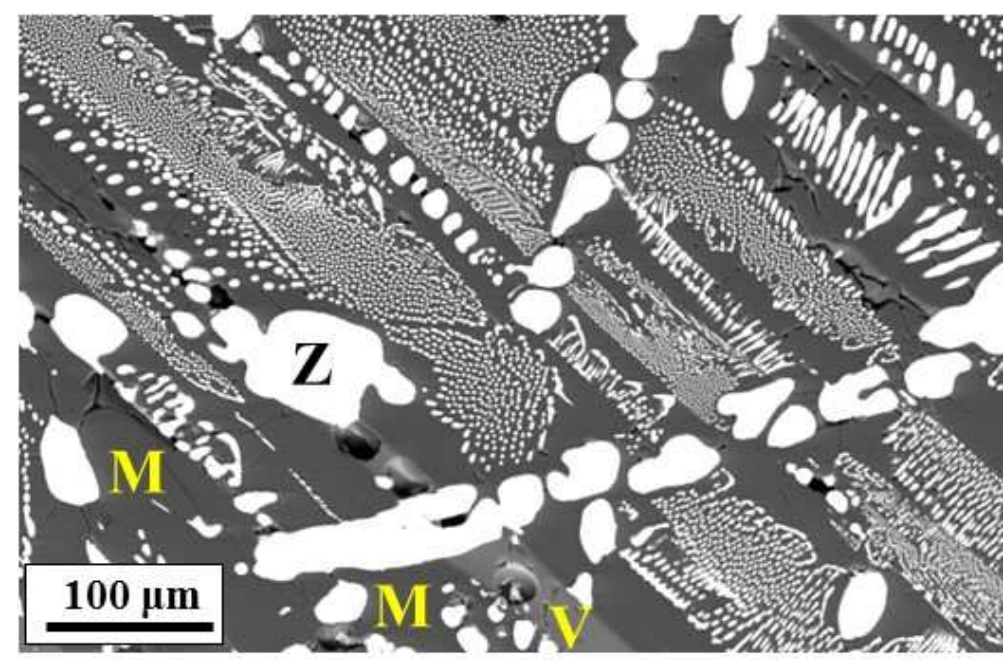

Fig.3. Microstructure of fused zirconia mullite grains, FZM -Imerys (backscattered electron SEM micrograph) (Z: zirconia, M: mullite, and V: glassy phase) 


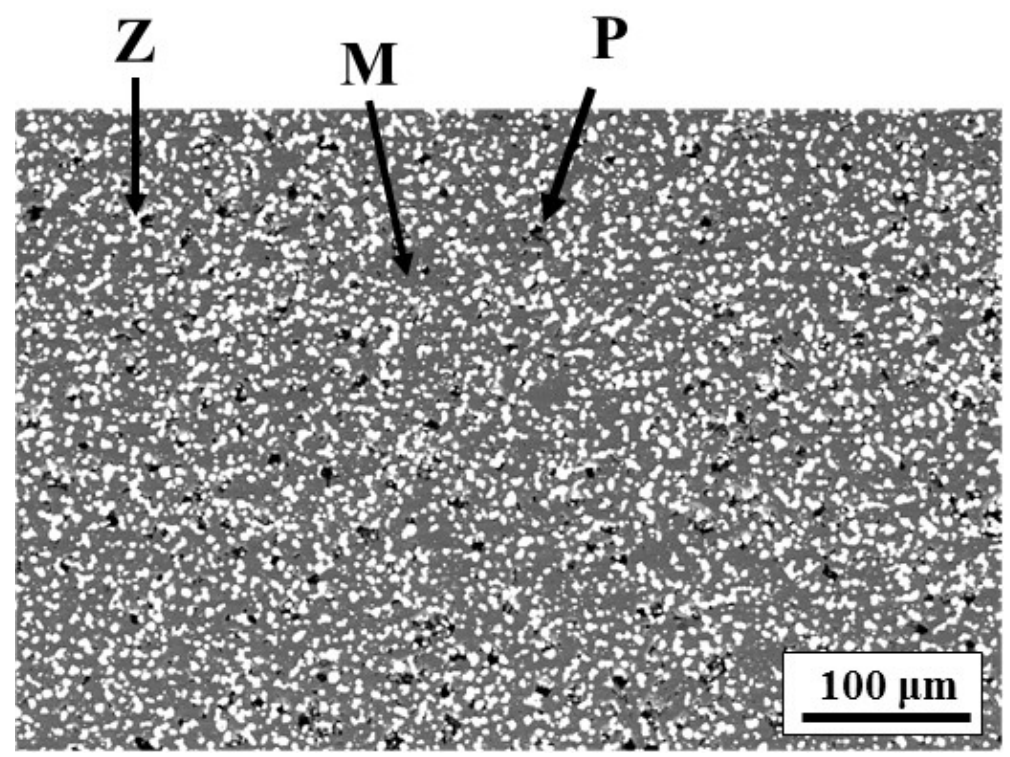

Fig. 4. Microstructure of commercial sintered zirconia mullite grains Z 72, Symulox ${ }^{\circledR}$ Nabeltec (backscattered electron SEM micrograph) (Z: zirconia, M: mullite, and P: pore)

To develop a new composite grain with better corrosion and thermal shock resistances, it is necessary to optimize the microstructure and to select appropriate raw materials.

Andalusite is an interesting precursor of mullite. Because of its microstructure, the use of mullitized andalusite in refractory materials contributes to improvement in the thermal shock resistance. From an economic point of view, an interesting source of zirconia is zircon. Zircon transforms into zirconia and silica, and andalusite leads to mullite and silica. The excess silica in andalusite after forming mullite can interact with the added alumina to form additional mullite. The raw materials, whose chemical compositions are indicated in Table 1, are mixed with the following molar ratio: Andalusite $(0.43$ mole $)+$ Zircon $(0.43$ mole $)+$ Alumina (0.94 mole $) \rightarrow$ Mullite $(0,44$ mole $)+$ Zirconia $(0.43$ mole $)$.

A sintered zirconia mullite raw material was developed from zircon $\left(\mathrm{ZrSiO}_{4}\right)$, alumina $\left(\mathrm{Al}_{2} \mathrm{O}_{3}\right)$ and andalusite $\left(\mathrm{SiO}_{2} \cdot \mathrm{Al}_{2} \mathrm{O}_{3}\right)$. The composition of the grains is $78.1 \mathrm{wt}$ \% mullite, 21.6 wt.\% zirconia and 0.3 wt.\% impurities. The details of the manufacturing are presented in section 3.4 .

The main challenge was lowering the sintering temperature. The temperature of decomposition of mullite and zircon had to be compatible with the sintering furnaces of the refractory industry (approximately $1600{ }^{\circ} \mathrm{C}$ ). The andalusite and zircon (as precursors of mullite and zirconia) transformations at a temperature lower than $1600{ }^{\circ} \mathrm{C}$ are described below. 


\subsection{Andalusite used as a precursor of mullite}

Andalusite, a natural mineral from low-grade metamorphic rock, is available as granular particles up to $8 \mathrm{~mm}$ in diameter, which are composed of single crystals or fragments of single crystals. Andalusite consists of $\mathrm{Al}_{2} \mathrm{SiO}_{5}$ crystals and some mineral impurities such as quartz, biotite, pyrite, and albite.

By heating above $1280{ }^{\circ} \mathrm{C}$, andalusite yields mullite and silica [16]. Mullitization of andalusite yields a composite made of mullite and silica-rich glass produced according to the reaction:

$$
3\left(\mathrm{Al}_{2} \mathrm{O}_{3} \mathrm{SiO}_{2}\right) \rightarrow 3 \mathrm{Al}_{2} \mathrm{O}_{3} 2 \mathrm{SiO}_{2}+\mathrm{SiO}_{2}
$$

Approximately $83 \mathrm{wt} . \%$ of the heated product becomes mullite above $1280{ }^{\circ} \mathrm{C}$, and the other $17 \mathrm{wt} . \%$ is a silica-rich glass. A fraction of the silica-rich liquid is expelled from the initial andalusite grain $[17,18]$. The main part of the silica-rich liquid was trapped in the initial grain and formed a capillary network of interconnected tubes with a diameter in the micrometre range and was elongated along the $\mathrm{c}$ axis common to the neoformed mullite and the parent andalusite crystal (Fig. 5.).

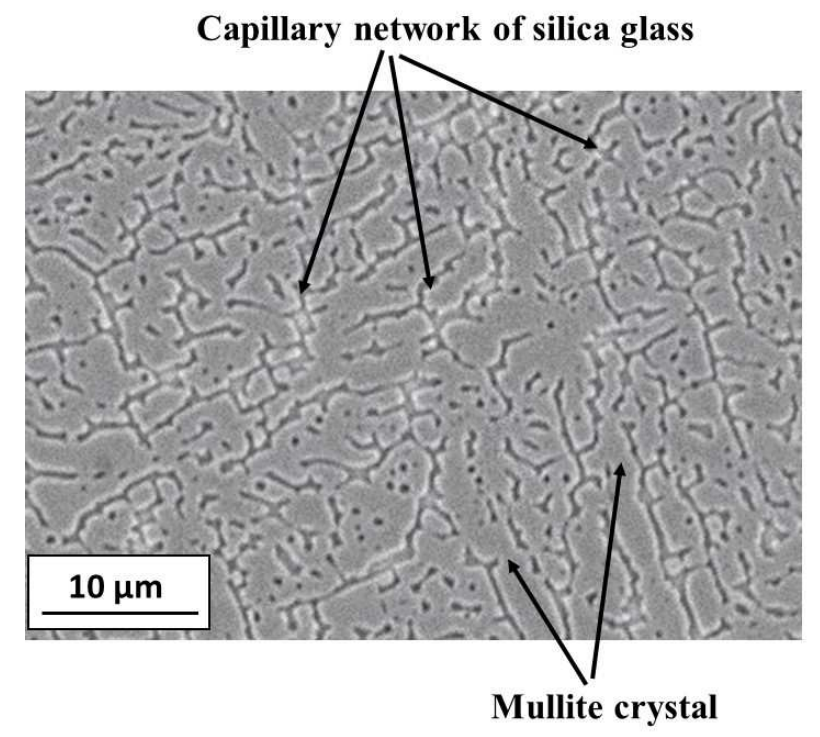

Fig. 5. Polished section of an andalusite grain transformed into a mullite-glass composite by heating to $1700{ }^{\circ} \mathrm{C}$ (backscattered electron SEM micrograph)

Mullitization proceeds as a pseudo morphosis, retaining the shape of the initial andalusite grain. Mullite is topotactically oriented relative to the andalusite host crystal [16,19,20,21]. 
Despite the presence of this glassy phase, the refractory products developed with andalusite show excellent creep resistance and thermal shock resistance. This is due to the specific microstructure of the mullitized andalusite, as shown in Fig. 5.

J. Poirier et al. have studied the thermal shock behaviour of andalusite and mullitized crystals using ultrasonic methods [22]. The polished grains, size up to $8 \mathrm{~mm}$, were submitted to successive thermal shocks. They were heated (at a heating rate of $300{ }^{\circ} \mathrm{C} / \mathrm{h}$ ) at $1200{ }^{\circ} \mathrm{C}$ for two hours, then quenched at room temperature. Scanning electron microscopy (SEM) micrographs revealed that at high temperature, by capillary action, the silica-rich vitreous phase filled the network of cracks created by the previous thermal shock. This melting phase, arising owing to alkalis and iron contained in the minor mineral inclusions of andalusite (quartz, phyllosilicates, and ilmenite), prevents the existing cracks and stops the new cracks that will be generated by the next thermal shock [22].

During thermal treatment and thermal shock, the behaviour of the mullitized andalusite crystals depends on the microstructure of the mullite-glass composite. The mullitized andalusite crystals exhibited a behaviour typical of composite materials; the microcracks were deflected and stopped in glass zones. Each additional heating/cooling cycle (heating rate: 300 ${ }^{\circ} \mathrm{C} / \mathrm{h}$, cooling rate: $220{ }^{\circ} \mathrm{C} / \mathrm{min}$ ) led to the repairing of the existing cracks (Fig. 6).

As shown in the paper [22], this microstructure evolution led to excellent thermal shock resistance compared to that of monolithic monocrystalline mullite. Andalusite-based refractories are well-suited for thermal cycling use. These results offer interesting possibilities for the development of innovative refractories using andalusite raw materials with an optimized microstructure.

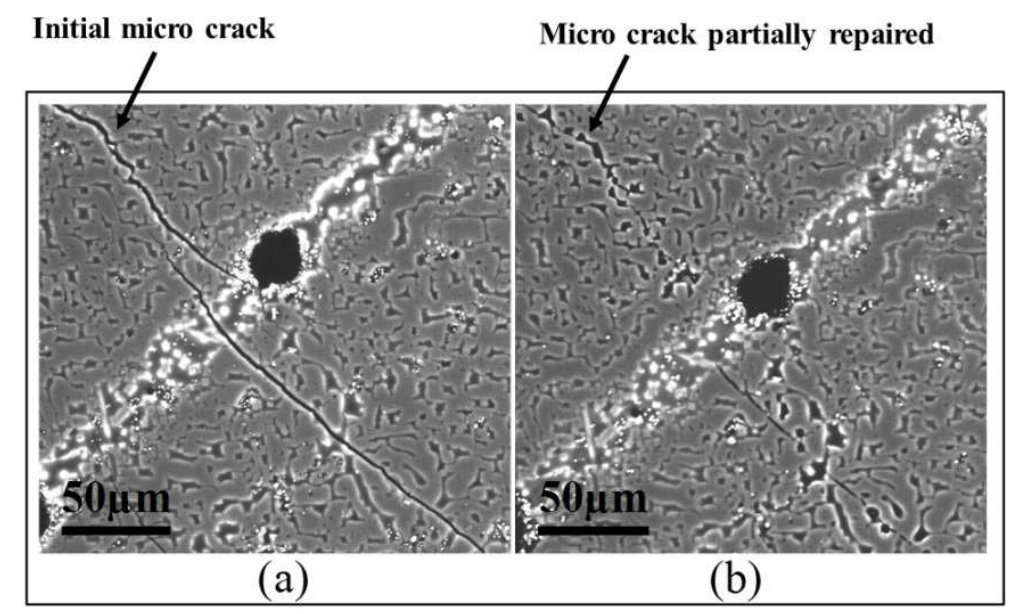

Fig. 6. Evolution of microcracks during heating/cooling cycle 
(a) Microcracks generated by the first thermal shock.

(b) After a second heating (at $1200{ }^{\circ} \mathrm{C}$ ) and a second thermal shock, the existing crack is partially repaired by the heating [23].

Backscattered electron SEM micrographs of a polished section (parallel to the (001) plane of the initial andalusite)

To increase the amount of mullite and to decrease the amount of the glassy phase in the composite, which contains approximately 83 wt.\% of mullite and 17 wt.\% of silica-rich glass, alumina powder was mixed with andalusite grains.

During sintering, the free silica-rich liquid expelled out of the grains reacted with alumina to create a secondary mullite according to the reaction:

$$
3 \mathrm{Al}_{2} \mathrm{O}_{3}+2 \mathrm{SiO}_{2} \rightarrow 3 \mathrm{Al}_{2} \mathrm{O}_{3} 2 \mathrm{SiO}_{2}
$$

The secondary mullite precipitates from a transient liquid phase containing silica and alumina. This secondary mullite may act as a ceramic binder between the primary mullite composite grains. After two hours at $1600{ }^{\circ} \mathrm{C}$, the obtained material was composed of the mullite phase (94 wt.\%) and residual glass (6 wt.\%) [24]. These reactions led to the production of a sintered material with a high mullite content. The batch formula, mixing, shaping and sintering procedures are detailed in 3.4 paragraph.

\subsection{Zircon used as a precursor of zirconia}

Zircon $\left(\mathrm{ZrSiO}_{4}\right)$ is a naturally occurring zirconium silicate mineral, a very chemically and thermally stable compound. At very high temperatures, zircon decomposes to $\mathrm{ZrO}_{2}$ and $\mathrm{SiO}_{2}$ :

$$
\mathrm{ZrSiO}_{4} \rightarrow \mathrm{ZrO}_{2}+\mathrm{SiO}_{2}
$$

Many authors have studied the transformation of zircon into zirconia. According to the $\mathrm{ZrO}_{2}-$ $\mathrm{SiO}_{2}$ phase equilibrium diagram proposed by Kaiser et al. (Fig. 7) [25], the decomposition of pure zircon begins at $1673{ }^{\circ} \mathrm{C}$. However, the particle size, and the nature and amount of impurities influence the temperature and the rate of zircon decomposition. Kaiser et al. [25] have studied the thermal stability of $\mathrm{ZrSiO}_{4}$ based on annealing experiments with two different zircon powders of very close grains size and known impurities: a natural zircon powder $\left(98 \% \mathrm{ZrSiO}_{4}\right.$ purity and particles smaller than $\left.3 \mu \mathrm{m}\right)$ and a synthetic powder $\left(100 \% \mathrm{ZrSiO}_{4}\right.$ purity and particles smaller than $4 \mu \mathrm{m}$ ). The decomposition starts between $1450{ }^{\circ} \mathrm{C}$ (for $98 \%$ $\mathrm{ZrSiO}_{4}$ purity) and $1600{ }^{\circ} \mathrm{C}$ (for $100 \% \mathrm{ZrSiO}_{4}$ purity). The decomposition is rather low at temperatures below $1650{ }^{\circ} \mathrm{C}$ (degree of $\mathrm{ZrSiO}_{4}$ decomposition $<5 \%$ ) and is high at temperatures above $1700{ }^{\circ} \mathrm{C}$. Zircon decomposes by a solid-state reaction releasing silica. 


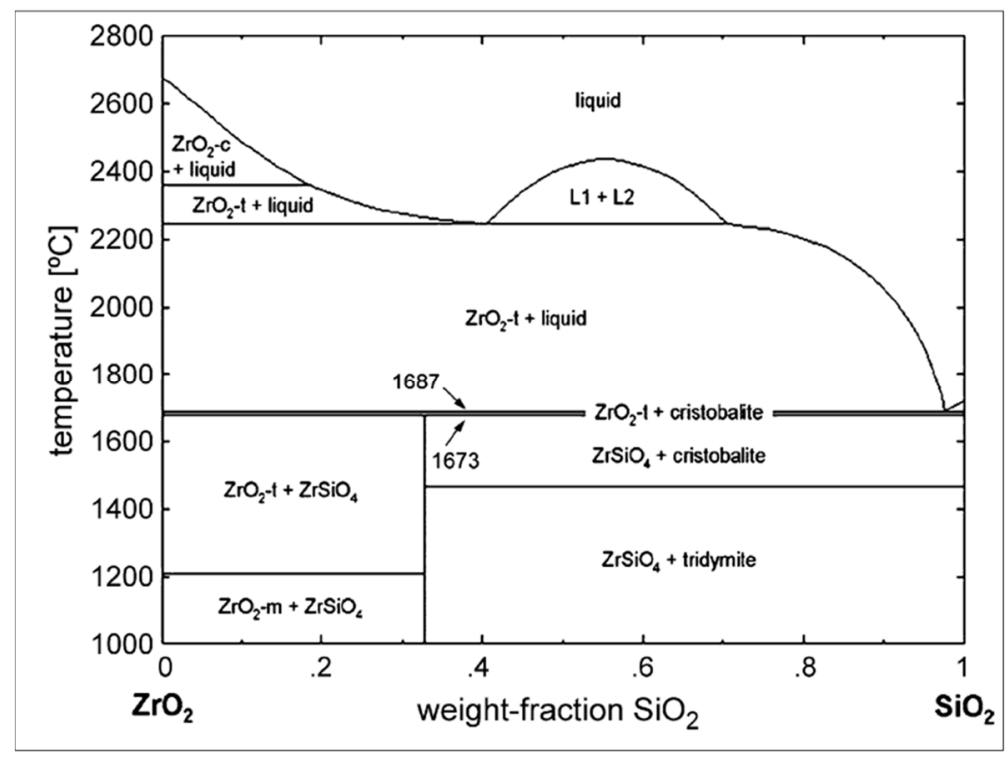

Fig. 7. $\mathrm{ZrO}_{2}-\mathrm{SiO}_{2}$ phase equilibrium diagram [25]

Figure 8 shows the degree of $\mathrm{ZrSiO}_{4}$ decomposition and the monoclinic $\mathrm{ZrO}_{2} / \mathrm{ZrSiO}_{4}$ peak intensity ratio (which are similar data) as a function of temperature. The impurities influenced the temperature and the kinetics of zircon decomposition. They led to the formation of a lowmelting liquid phase and shifted the start of the dissociation to lower temperatures due to a liquid-solid reaction.

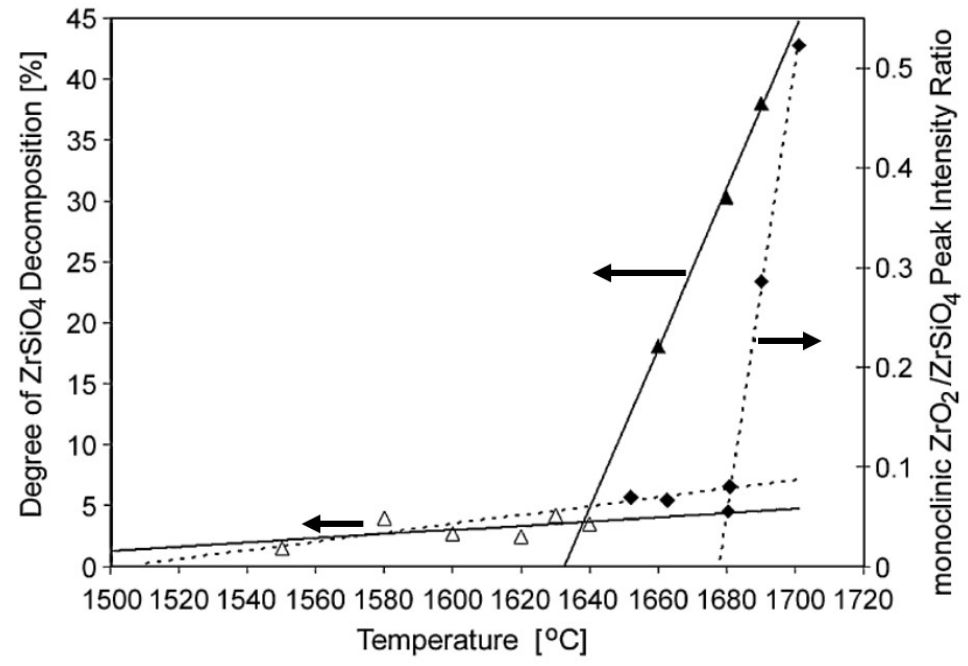

Fig. 8. Degree of zircon decomposition [25]: data of Anseau et al. $(\triangle \mathbf{\Delta})$ (purity $\left.=99,28 \% \mathrm{ZrSiO}_{4}\right)[26]$ and Klute $(\diamond)$ (purity $\left.=100 \% \mathrm{ZrSiO}_{4}\right)$ [27]. 


\subsection{Effect of the addition of andalusite on the temperature and the kinetics of zircon decomposition}

Since impurities strongly influence the decomposition temperature of zircon into zirconia, it is of interest to add andalusite to the zircon powder. Indeed, at high temperature, the andalusite transforms into mullite and silica-rich glass containing impurities.

In the publication [23], M.L. Bouchetou et al. have studied the role of impurities on the mullitization of fired andalusite grains. The impurities are concentrated in the silica rich glass which contains potassium $\left(\mathrm{K}_{2} \mathrm{O} \approx 1-3\right.$ wt.\%), iron oxides $\left(\mathrm{Fe}_{2} \mathrm{O}_{3} \approx 1-3\right.$ wt.\%) and other elements; with amounts below $1 \mathrm{wt} . \%$. This low-melting glass shifts the initial dissociation of zircon to lower temperatures. 1-2 mm KF andalusite grains (Imerys) and fine $(<10 \mu \mathrm{m})$ zircon powder (Ceradel), whose chemical compositions are given in Table 1, were mixed (wt.\% ratio 1/1). The samples (diameter $1 \mathrm{~cm}$ - thickness $5 \mathrm{~mm}$ ) were pressed, dried (at $150{ }^{\circ} \mathrm{C}$ for $0.5 \mathrm{~h}$ ) and heated for an hour at $1600{ }^{\circ} \mathrm{C}$ (heating rate of $900{ }^{\circ} \mathrm{C} / \mathrm{h}$ and free cooling). The SEM micrographs show the very interesting influence of the andalusite grains. The transformation of zircon into zirconia only initiated close to the andalusite grains (Fig. 9 and Fig. 10).

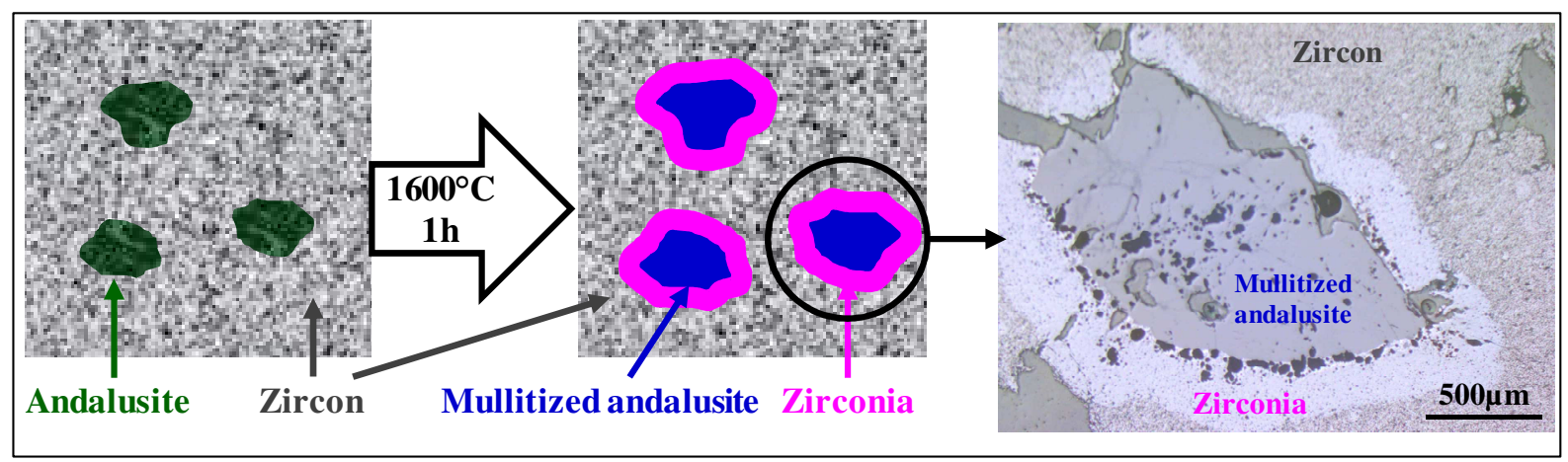

Fig. 9. Polished section of coarse andalusite grains surrounded by fine zircon and heated for 1 hour at $1600{ }^{\circ} \mathrm{C}$ (optical micrograph)

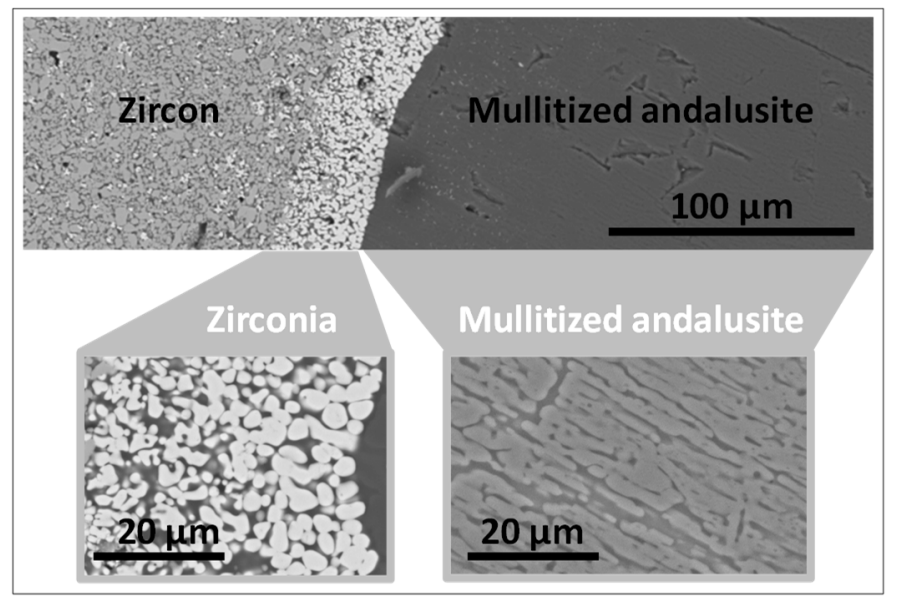


Fig. 10. Interface between a coarse andalusite grain and with fine zircon powder after heating for 1 hour at $1600{ }^{\circ} \mathrm{C}$ (backscattered electron SEM micrographs)

Note that the thickness of the zirconia layer in Fig. 10 is smaller than the layer in Fig.9. This difference is explained by the local variations of silica rich glass composition that may be attributed to the initial distribution of mineral impurities in andalusite grains.

To study the influence of temperature on the zircon decomposition, samples made of 28.47 wt.\% fine $\mathrm{KF}$ andalusite $(>10 \mu \mathrm{m}), 32.1 \mathrm{wt} . \%$ fine zircon and $39.47 \mathrm{wt} \%$ CT3000 alumina were mixed. These samples ( $1 \mathrm{~cm}$ diameter $-5 \mathrm{~mm}$ thickness) were dried, pressed under a pressure application of 5 tons $\left(62,4 \mathrm{kN} / \mathrm{cm}^{2}\right)$, then heated at $1600{ }^{\circ} \mathrm{C}$ at temperatures ranging from $1300-1600{ }^{\circ} \mathrm{C}$ for 1 hour (heating rate of $900{ }^{\circ} \mathrm{C} / \mathrm{h}$ and free cooling).

After heating, the phases were analysed by X-ray diffraction (XRD) (Table 4). Samples heated for an hour at $1600{ }^{\circ} \mathrm{C}$ were found to have andalusite transformed into mullite, and a fraction of zircon was decomposed into zirconia (Fig. 11).

\begin{tabular}{|c|c|c|c|c|}
\hline $\begin{array}{c}\text { Temperature } \\
\left({ }^{\circ} \mathrm{C}\right)\end{array}$ & $\begin{array}{c}\text { Andalusite } \\
\mathrm{SiO}_{2} \cdot \mathrm{Al}_{2} \mathrm{O}_{3}\end{array}$ & $\begin{array}{c}\mathrm{Zircon} \\
\mathrm{ZrSiO}_{4}\end{array}$ & $\begin{array}{c}\text { Mullite } \\
2 \mathrm{SiO}_{2} \cdot 3 \mathrm{Al}_{2} \mathrm{O}_{3}\end{array}$ & $\begin{array}{c}\text { Baddeleyite } \\
\mathrm{ZrO}_{2}\end{array}$ \\
\hline $1300^{\circ} \mathrm{C}$ & ++ & +++ & Traces & - \\
\hline $1400^{\circ} \mathrm{C}$ & Traces & +++ & ++ & - \\
\hline $1500^{\circ} \mathrm{C}$ & - & +++ & ++ & - \\
\hline $1600^{\circ} \mathrm{C}$ & - & ++ & +++ & +++ \\
\hline \multicolumn{7}{|c|}{++ minor phase } \\
\hline
\end{tabular}

Table 4. Crystallized phases formed after firing 28.47 wt.\% KF andalusite, 32.1 wt.\% zircon and 39.47 wt.\% CT3000 alumina samples at temperatures ranging from $1300-1600{ }^{\circ} \mathrm{C}$ for 1 hour

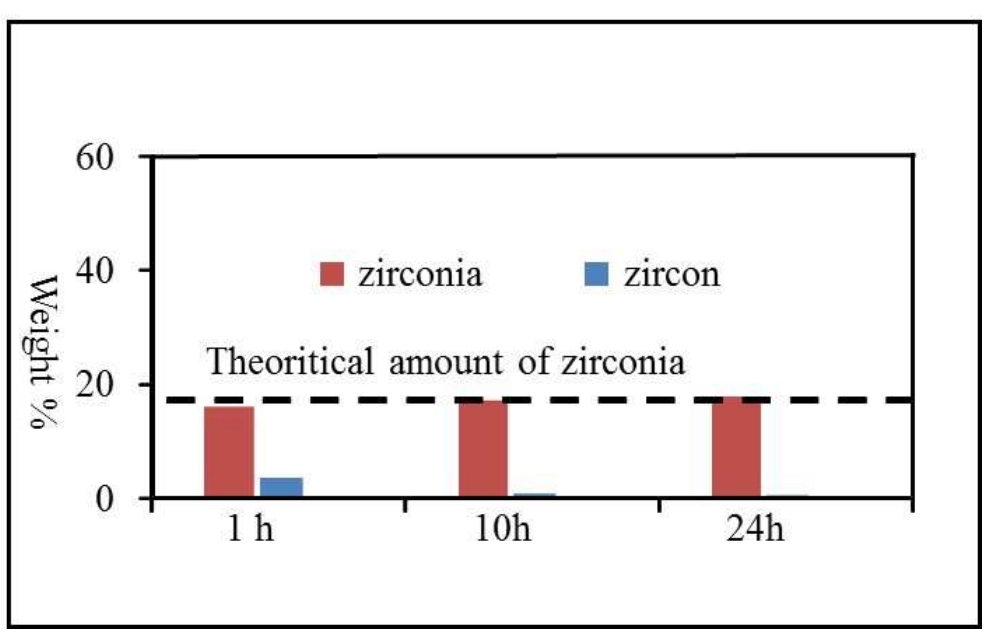


Fig.11. Amount of zircon and zirconia (XRD with the Rietveld method) after a heating at $1600{ }^{\circ} \mathrm{C}$ in air, with different hold times: 1,10 and 24 hours. The initial mixture was 28.47 wt.\% KF andalusite, 32.1 wt.\% zircon and 39.47 wt.\% CT 3000 alumina.

Furthermore, while some authors $[26,27]$ have shown that at $1600{ }^{\circ} \mathrm{C}$ the degree of zircon decomposition is very low. Anseau et al. [26] studied the thermal decomposition of natural Australian zircon sand. Its chemical composition (wt.\%) was: $99.13 \% \mathrm{ZrO}_{2}, 0.32 \% \mathrm{Al}_{2} \mathrm{O}_{3}$, $0.25 \% \mathrm{TiO}_{2}, 0.15$ wt. $\% \mathrm{Fe}_{2} \mathrm{O}_{3}$ ). The samples were heated at $300{ }^{\circ} \mathrm{C} / \mathrm{min}$ to temperatures between 1400 and $1690{ }^{\circ} \mathrm{C}$ for 8 hours. The degree of zircon decomposition was measured by the $\mathrm{ZrO}_{2} / \mathrm{ZrSiO}_{4}$ ratio as recorded by $\mathrm{XRD}$ as well as by chemical analysis of the amount of free $\mathrm{SiO}_{2}$. The decomposition starts between 1525 and $1550{ }^{\circ} \mathrm{C}$ at a relatively low velocity, but by approximately $1650{ }^{\circ} \mathrm{C}$, the reaction accelerates significantly.

Klute [27] synthetized high-purity zircon powder from precipitation and thermally decomposition at $1050{ }^{\circ} \mathrm{C}$ of ethyl silicate and zirconyl sulfate, dispersed in an aqueous solution. These powders were heated for 1-2 days in air at various temperatures, quenched and characterised by XRD. The binary eutectic between $\mathrm{ZrO}_{2}$ and $\mathrm{SiO}_{2}$ was determined at $1699 \pm 3{ }^{\circ} \mathrm{C}$. The addition of andalusite leads to a complete decomposition of zircon after 10 hours at $1600^{\circ} \mathrm{C}$.

The decomposition of zircon leads to zirconia and a liquid phase. Furthermore, in this liquid phase, $\mathrm{K}_{2} \mathrm{O}$ and $\mathrm{Na}_{2} \mathrm{O}$ close to the zirconia grains are detected by EDS analysis.

Majidian et al. [10] had studied the phase evolution and the microstructures of aluminamullite-zirconia composites mixed using Iranian andalusite and have shown similar results.

The suspensions were prepared by mixing alumina and zircon (85:15 wt. \% ratio) with 0,2,5 and 10 wt. $\%$ of andalusite powder, then dried and granulated. The green samples were sintered at 1500,1600 and $1650{ }^{\circ} \mathrm{C}$.

H. Pooladvand et al [28] had investigated the effects of alumina and zirconia addition on transformation of andalusite to mullite. Alumina - zirconia - mullite composites were prepared by adding zirconia to andalusite with a mass ration of $0.24: 0.78$ and a mass ratio of 0.28 alumina/0.72 andalusite was chosen to form secondary mullite during andalusite transformation.

It has been found that andalusite powder can reduce the decomposition temperature of zircon to $1600{ }^{\circ} \mathrm{C}[10,28]$ and accelerate the sintering of alumina-zircon, which leads to an increase of the mullite amount and improves the thermal shock resistance of the alumina-mullitezirconia composite. 
The presence of 28.47 wt.\% andalusite enables the complete decomposition of 32.1 wt.\% zircon, with andalusite impurities forming a liquid phase that promotes diffusion. The microstructure contains mullite, zirconia grains and an amorphous phase homogeneously distributed in the mullitized andalusite.

The introduction of low-melting additives such as alkali in the mix is a complementary approach to enhancing the zircon decomposition. The influence of the $\mathrm{Na}_{2} \mathrm{O}$ and $\mathrm{K}_{2} \mathrm{O}$ alkalis was studied by introducing a small quantity of $\mathrm{Na}_{2} \mathrm{CO}_{3}$ and $\mathrm{K}_{2} \mathrm{CO}_{3}$ in the mixture of andalusite KF (28.47 wt.\%), zircon (32.1 wt.\%) and alumina CT3000 (39.47 wt.\%). Thirty samples were made with contents of $\mathrm{K}_{2} \mathrm{O}$ and $\mathrm{Na}_{2} \mathrm{O}$ ranging from 0.5-2.0 wt. \% under the same pressing and heating conditions as the previous samples. After heating at $1600{ }^{\circ} \mathrm{C}$, the amount of zirconia and zircon was determined by XRD analysis (Fig. 12).

(a) : $1 \mathrm{~h}-1600^{\circ} \mathrm{C}$

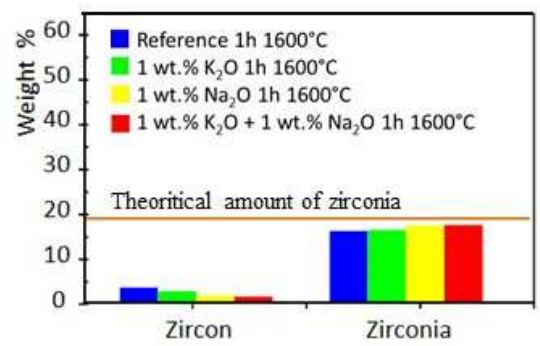

(b) : $10 \mathrm{~h}-1600^{\circ} \mathrm{C}$

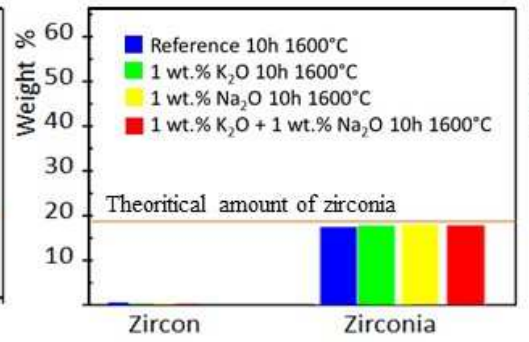

(c) : $24 \mathrm{~h}-1600^{\circ} \mathrm{C}$

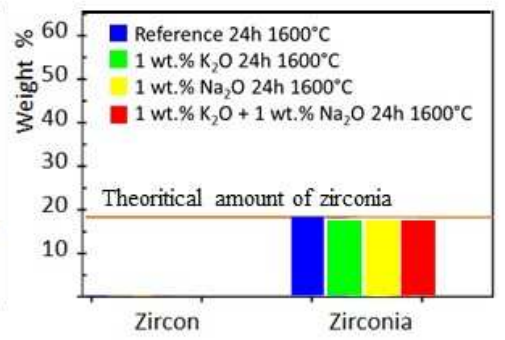

Fig. 12. Influence of alkali additives on the amount of zircon and zirconia after 1 hour (a), 10 hours (b) and 24 hours (c) at $1600{ }^{\circ} \mathrm{C}$

The introduction of $\mathrm{Na}$ and $\mathrm{K}$ alkali additives had a beneficial influence on the transformation of zircon into zirconia only during the first hour of the heat treatment at $1600{ }^{\circ} \mathrm{C}$. The amount of alkaline additives has a very low impact on the reaction rate. After 10 hours at $1600{ }^{\circ} \mathrm{C}$, without the additional alkalis, all the zircon was transformed into zirconia.

\subsection{Shaping and sintering of the zirconia-mullite raw material}

Test samples $(10 \times 15 \times 40 \mathrm{~mm}$ size $)$ were prepared from andalusite, alumina and zircon powders, shaped by slip casting in a plaster mould, and after drying, were sintered at $1600{ }^{\circ} \mathrm{C}$ in air. The batch formula, mixing, casting and sintering procedure are detailed in Fig.13. 


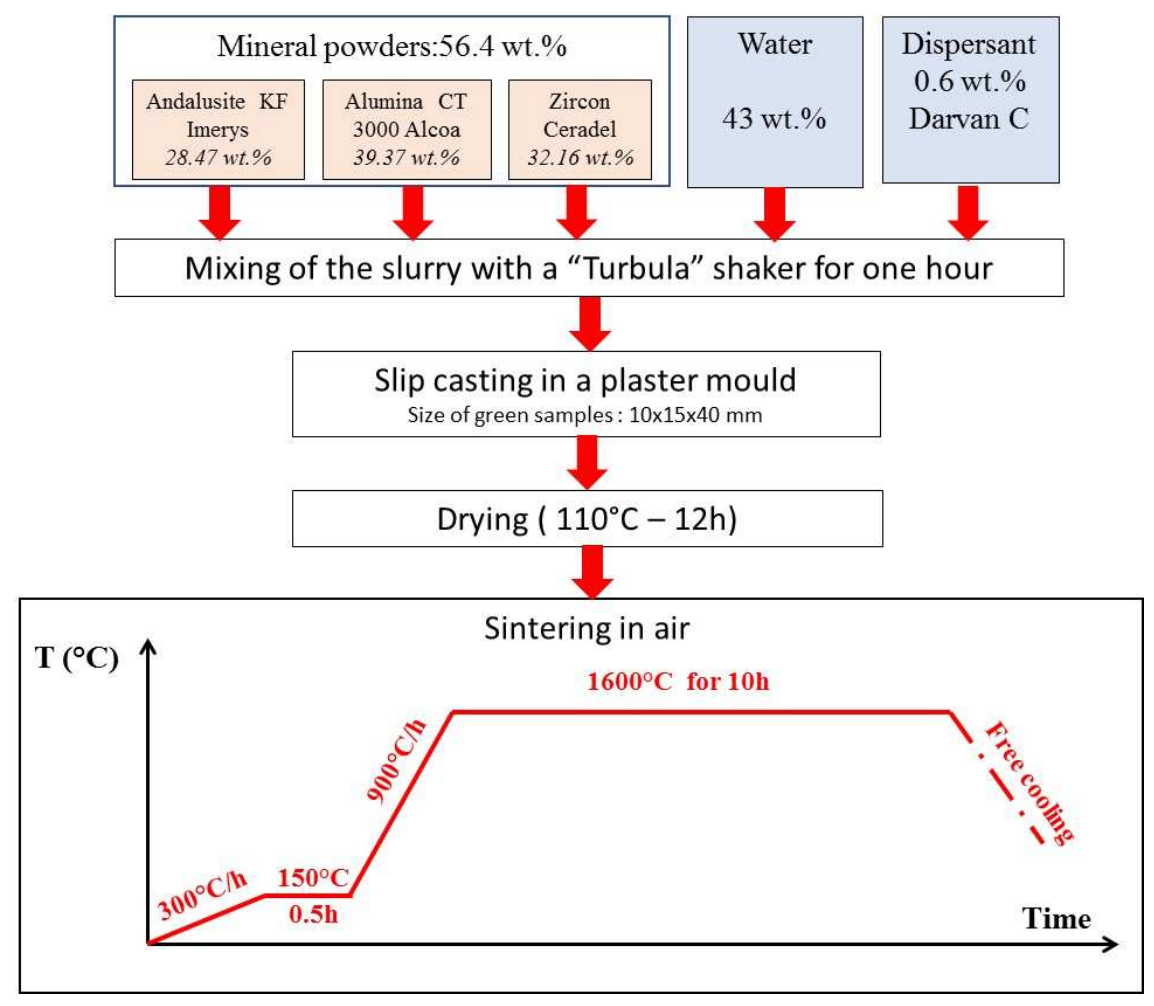

Fig. 13- Manufacturing process of zirconia-mullite raw material

During sintering, several reactions occurred at high temperature (Fig. 14). The andalusite transformed into a mullite and a silica-rich glass. This reaction started at approximately 1300 ${ }^{\circ} \mathrm{C}$. Zircon decomposed to yield zirconia and silica. The silica rich glass formed reacted with the added alumina to crystallize and form secondary mullite.

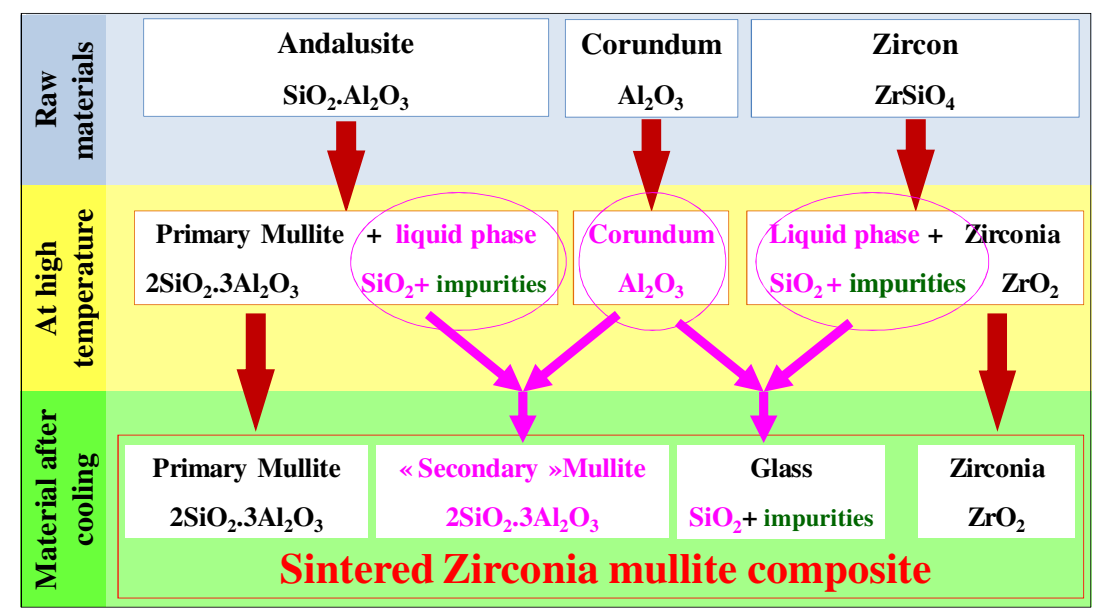

Fig. 14. Phases formed by sintering a mixture of andalusite, corundum, and zircon fired at $1600{ }^{\circ} \mathrm{C}$ in air for 10 hours

After 10 hours at $1600{ }^{\circ} \mathrm{C}$, the sintered zirconia mullite raw material contained $74 \mathrm{wt} . \%$ mullite $\left(2 \mathrm{SiO}_{2} .3 \mathrm{Al}_{2} \mathrm{O}_{3}\right), 19$ wt.\% zirconia $\left(\mathrm{ZrO}_{2}\right)$ and 7 wt.\% glassy phases (determined by XRD analysis with the Rietveld method). The sintered composite had a microstructure 
consisting essentially of homogeneously distributed fine zirconia particles in a mullite rich glassy matrix. The average particle diameter of the zirconia particles was less than $5 \mu \mathrm{m}$ (Fig.15). The crystallization of mullite from the silica and the added alumina allowed the densification of the material. The open porosity after 10 hours at $1600{ }^{\circ} \mathrm{C}$ was very low $(<3 \%)$. The use of zircon associated with andalusite and alumina formed a sintered zirconia mullite composite at $1600^{\circ} \mathrm{C}$.

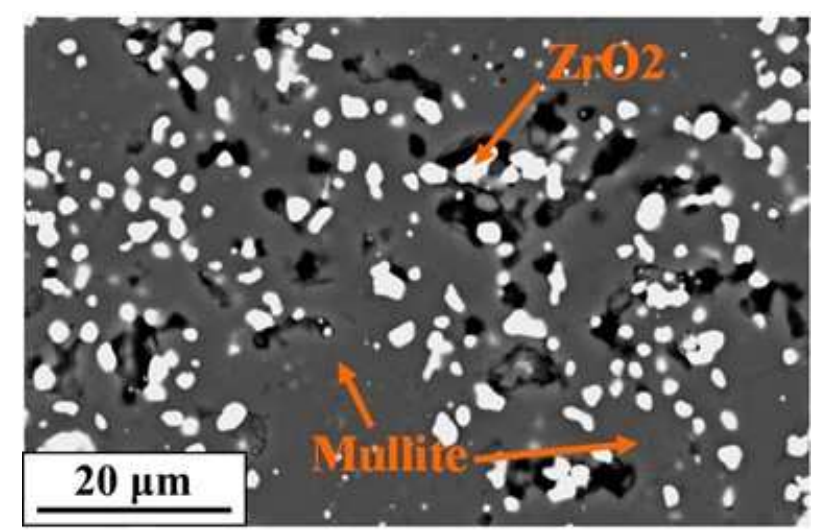

Fig.15. Microstructure of the sintered zirconia mullite composite (backscattered electron SEM micrograph)

\section{Properties of the sintered zirconia-mullite raw material}

In use, refractory materials are subject not only to corrosion by glass or slag but also to thermal shock stresses. The corrosion and thermal shock resistances of this synthesized zirconia mullite raw material were evaluated and compared to other commercial raw materials.

\subsection{Corrosion resistance}

Zirconia in mullite and alumina grains improves the corrosion resistance because zirconia has a lower solubility than mullite and alumina in soda-lime glass and slag. Mullite and alumina are dissolved in the glassy phase, and thus, random needle-like corundum or mullite crystals are formed and begin to grow in the corroded area, during cooling [29, 30, 31]. Askel [29] has observed that zirconia grains in alumina mullite zirconia refractories served as an effective corrosion barrier in the corroded zone. Zirconia creates a stable interface and increases the corrosion resistance.

The corrosion resistance of the sintered zirconia mullite grains against molten corrosive agents was tested. Two different corrosive agents were used: a soda-lime glass (71.6 wt.\% 
$\mathrm{SiO}_{2}-14.2 \% \mathrm{Na}_{2} \mathrm{O}-9.5 \% \mathrm{CaO}-4.7 \% \mathrm{MgO}$ ) provided by Ceradel and an alumina-lime slag (50 wt.\% $\mathrm{Al}_{2} \mathrm{O}_{3}-50$ wt.\% $\mathrm{CaO}$ ) made in our laboratory by melting an alumina (50 wt.\%) - lime (50 wt.\%) mixture at $1600{ }^{\circ} \mathrm{C}$, for 5 hours. Alumina crucibles were filled with the zirconiamullite grains $(7 \mathrm{gr})$ on which was placed a pressed powder of slag or glass $(0.5 \mathrm{gr})$. The crucibles were heated in an electric furnace for 10 minutes at $1550{ }^{\circ} \mathrm{C}$ using a heating rate of $300{ }^{\circ} \mathrm{C} / \mathrm{h}$. After air quenching, the samples were cut, polished, coated with carbon and observed with a scanning electron microscope. To estimate the corrosion, the depth of diffusion of the calcium in the grains was measured for every sample.

The results were compared with those obtained for a commercially available fused zirconia mullite material (FZM-Imerys) produced through a fusion process by melting a mixture of zircon and alumina, and a commercially available sintered zirconia mullite material ( $\mathrm{Z} 72$ Symulox ${ }^{\circledR}-$ Nabaltec), formed by a stoichiometric sintered mullite and microcrystalline baddeleyite zirconia. The mineralogical compositions of the initial grains (no corroded), determined by XRD analysis using the Rietveld method, are presented in Fig. 16.

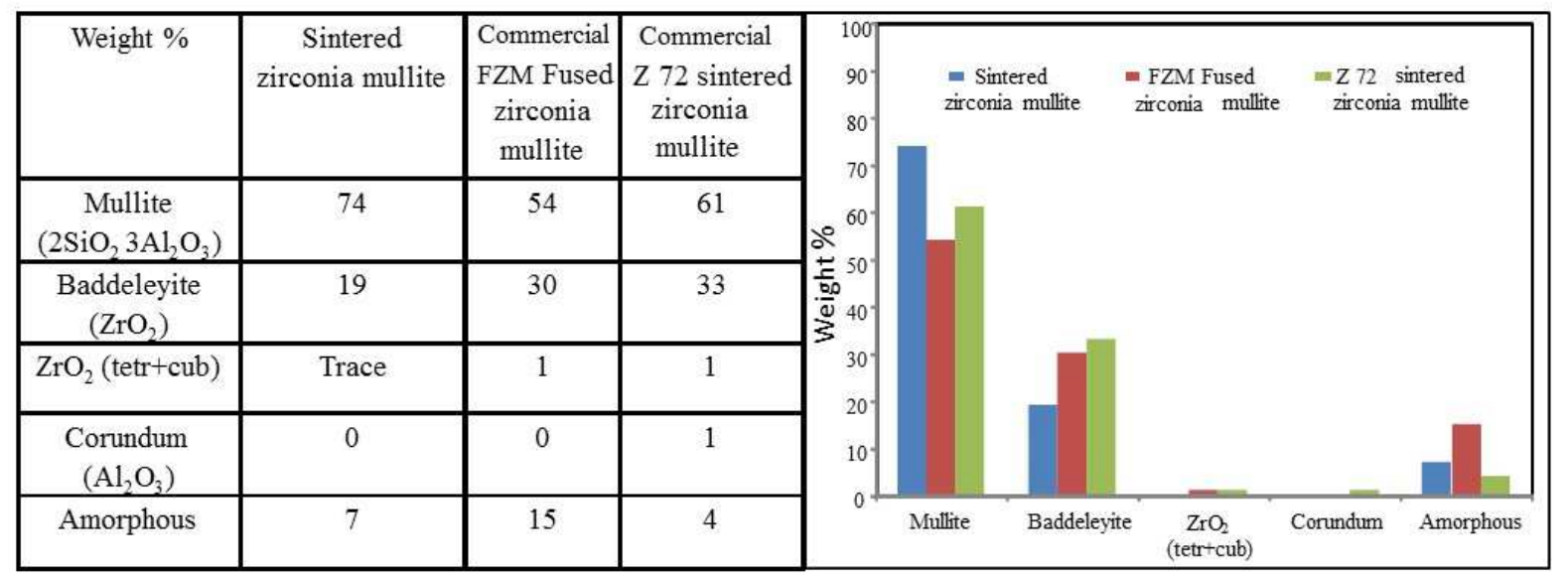

Fig.16. Initial mineralogical compositions of the grains (synthetized sintered zirconia-mullite, FZM commercial fused zirconia mullite, Z72 commercial sintered zirconia mullite)

Impregnation depth measurements of calcium (see SEM micrographs, Fig. 17 and Fig.18) and the histogram (Fig. 19) showed two different behaviours. The fused zirconia mullite grains were completely impregnated with calcium, while the sintered zirconia mullite and the commercial sintered zirconia mullite were only partially impregnated. As shown by Askel [29], needle-like corundum crystals form in the glassy phase of the corroded area.

The chemical composition of the glassy phase (composed of $\mathrm{Al}_{2} \mathrm{O}_{3}, \mathrm{SiO}_{2}, \mathrm{CaO}, \mathrm{Na}_{2} \mathrm{O}, \mathrm{MgO}$, $\mathrm{ZrO}_{2}$ oxides) close to the impregnated grain was determined by EDS analyses and the distribution of $\mathrm{Ca}$ element was determined by mapping. The viscosity of the glassy phase at high temperature was calculated using Urbain's model [32]. The results show that, at high 
temperatures, the viscosity of the glassy phase of the sintered zirconia mullite was always higher than the viscosity of the glassy phases of commercial FZM fused zirconia mullite and Z 72 sintered zirconia mullite (Fig. 20. ).

The sintered zirconia mullite and the commercial zirconia mullite showed similar impregnation behaviours at the beginning of the corrosion by glass or slag. Nevertheless, the viscosity of the liquid phase at high temperature (between 1200 and $1600{ }^{\circ} \mathrm{C}$ ) remained higher in the case of the sintered zirconia mullite composite synthesized using zircon and andalusite. The fused zirconia mullite product presented a lower corrosion resistance: the depth of penetration of the calcium was higher and the liquid phase (composed of $\mathrm{Al}_{2} \mathrm{O}_{3}, \mathrm{SiO}_{2}, \mathrm{CaO}$, $\mathrm{Na}_{2} \mathrm{O}, \mathrm{MgO}, \mathrm{ZrO}_{2}$ oxides) was substantially less viscous at high temperature (between 1200 and $\left.1600{ }^{\circ} \mathrm{C}\right)$.

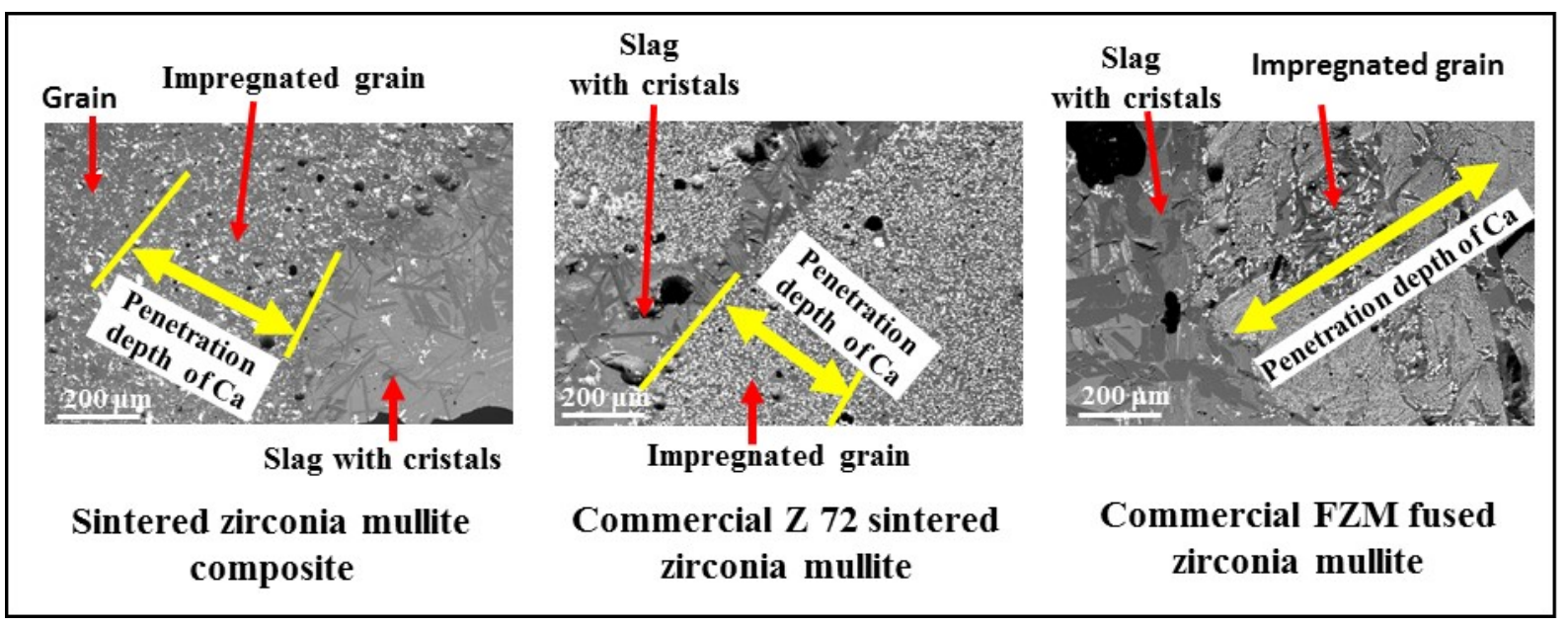

Fig.17. Microstructures of samples corroded by an alumina-lime-slag (backscattered electron SEM micrographs)

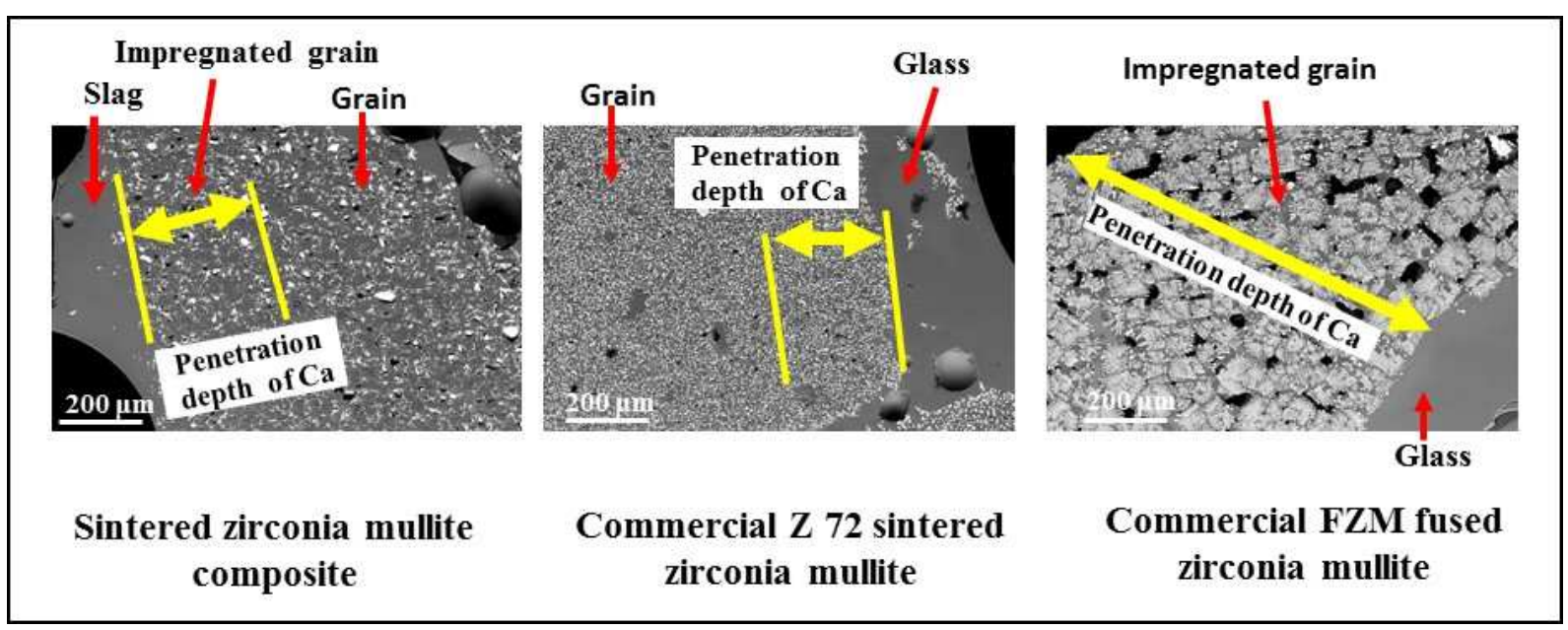


Fig. 18. Microstructures of samples corroded by a soda-lime glass. (backscattered electron SEM micrographs)

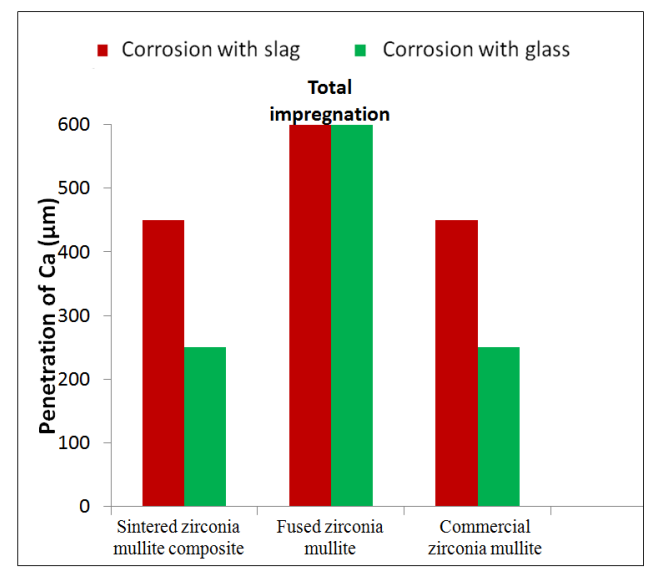

Fig.19. Penetration depth of $\mathrm{Ca}$ in the grains

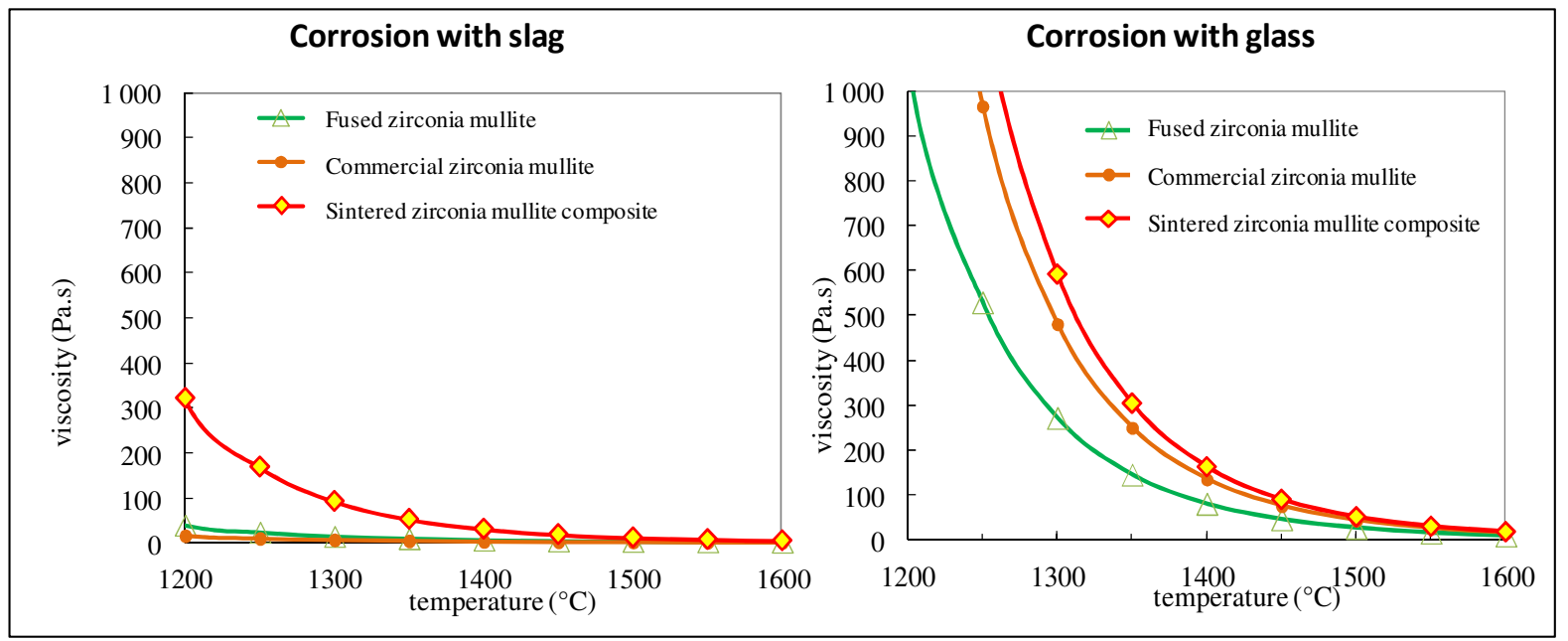

Fig. 20. Viscosity, calculated with Urbain's model [32], of the liquid phase close to the impregnated grains

\subsection{Thermal shock resistance and thermomechanical behaviour}

The thermal shock resistance of the zirconia mullite composite was evaluated by heating sintered samples (size $10 \times 15 \times 40 \mathrm{~mm}$ ) in air to $1200{ }^{\circ} \mathrm{C}$ for two hours and cooling to room temperature. The heating rate and the cooling rate were $300{ }^{\circ} \mathrm{C} / \mathrm{h}$ and $220{ }^{\circ} \mathrm{C} / \mathrm{min}$, respectively. Ultrasonic pulse echography in transmission mode was used to determine the evolution of the propagation wave velocity within the sample and to evaluate the effect on the thermal shock resistance. Fig. 21 shows the experimental procedure of the successive thermal shocks. 


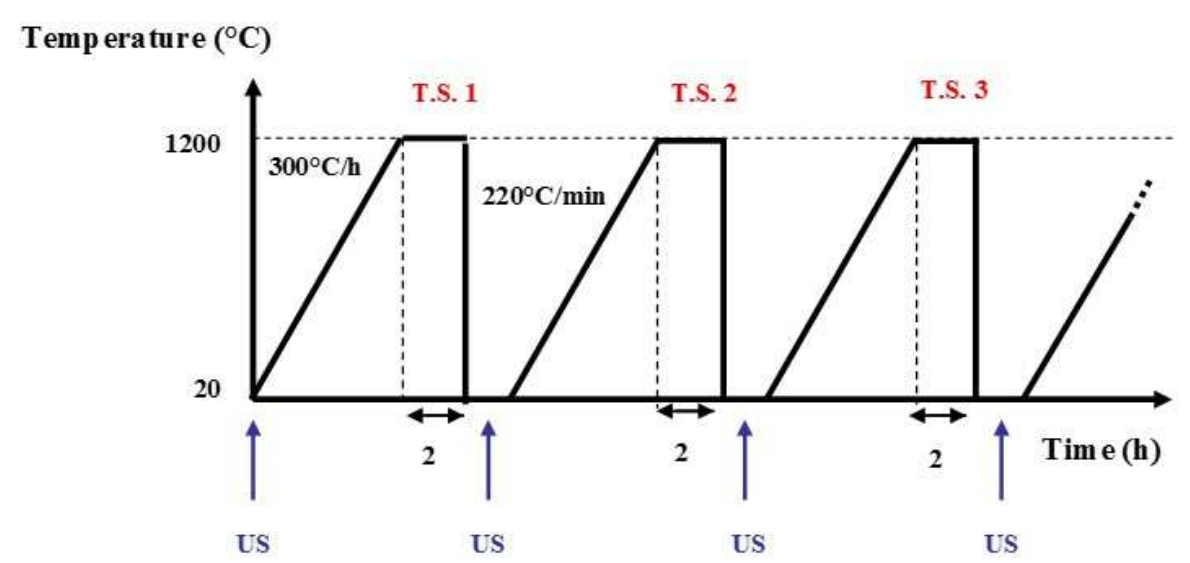

Fig. 21. Experimental procedure applied for thermal shock study on sintered samples

The results were compared to the results obtained for dense alumina (purity 98,5 wt.\%) and cordierite under the same thermal shock conditions, as shown in Fig. 22.

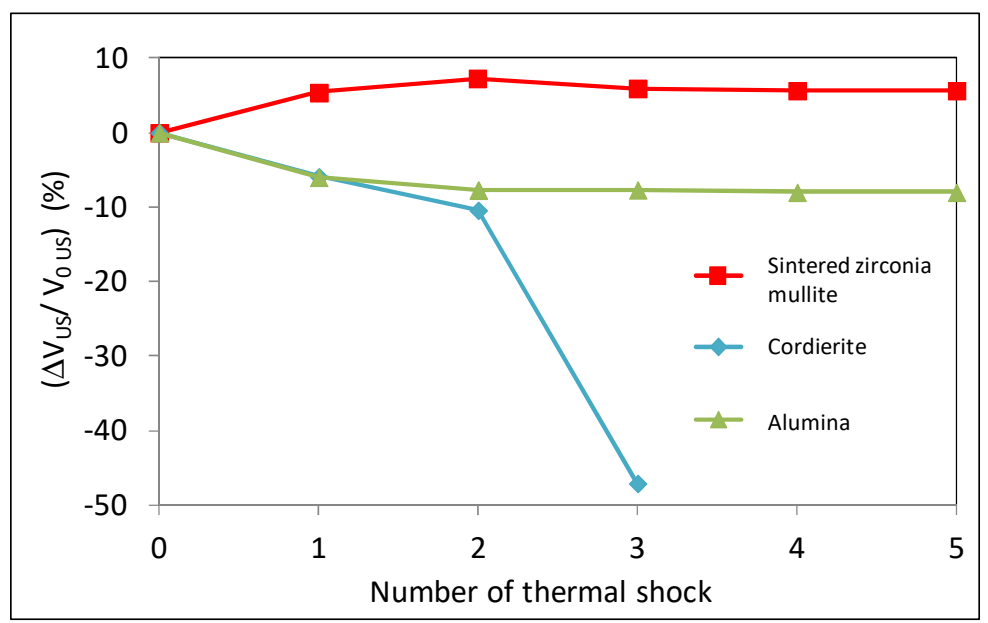

Fig. 22. Evolution of the relative ultrasonic wave velocity in sintered zirconia/mullite composites versus the number of thermal shocks $\left(1200{ }^{\circ} \mathrm{C}-20{ }^{\circ} \mathrm{C}\right.$.) compared with that of other refractory materials

The observed evolution of the relative velocity for the composite (slight increase and then stabilization) is quite unusual for such a material and indicates that the thermal shock resistance of the material is improved. However, if the tendency is clearly established, the magnitude of the variation has to be tempered by the value of the relative porosity of the sample, which could vary after several thermal shocks and is a conjugation of a damage mechanism (cracking) and repairing process. A liquid phase formed at $1200{ }^{\circ} \mathrm{C}$ has repaired the existing cracks generated by the previous thermal shock. 
The evolution of the same parameter plotted for other materials such as cordierite and alumina underlines a significantly different thermal shock behaviour with a fall observed starting from the first thermal shock.

Rendtorff et al. [5] studied the thermal shock behaviour of various mullite-zirconia/zircon composites. These composites were prepared by slip casting using mullite-zirconia electrofused grains and 15-25-35-45 wt.\% of zircon and were sintered at temperatures between 1300 and $1600{ }^{\circ} \mathrm{C}$ for 2 hours. The authors report that the thermal shock produces a decrease in the elastic properties mostly due to the onset of a microcracking network induced by the thermal expansion mismatch between phases. After two thermal cycles, Young's modulus remains constant, showing that the composite exhibits a high resistance to crack propagation.

Other authors $[2,3,7]$ have shown that the incorporation of fine zirconia grains in a mullite matrix results in a significant toughening. Different mechanisms such as stress-induced transformation, micro-cracking and crack deflection are involved in this toughening. The thermomechanical behaviour of this type of material is sensitive to the phase transformation of zirconia and depends on different parameters such as matrix stiffness, zirconia grain size and chemical composition [7,33].

Claussen and Jahne [33] have studies the mechanical properties of sintered, in situ-reacted mullite-zirconia composites. Mixtures of zircon and $\mathrm{Al}_{2} \mathrm{O}_{3}$, in ratios according to the reaction $2 \mathrm{ZrSiO}_{4}+3 \mathrm{Al}_{2} \mathrm{O}_{3} \rightarrow 3 \mathrm{Al}_{2} \mathrm{O}_{3} \cdot 2 \mathrm{SiO}_{2}+2 \mathrm{ZrO}_{2}$, were attrition-milled in water for 6 hours. The samples were isostatically pressed at $600 \mathrm{MPa}$ and sintered in air at less than the reaction temperature $\left(\sim 1450{ }^{\circ} \mathrm{C}\right)$. Claussen and Jahne have shown that during the sintering of zirconia mullite composites, two types of zirconia grains, which are not stabilized, can be observed. They found that the major fraction consists of monoclinic zirconia grains, and the other fraction contains very small tetragonal zirconia grains. Microcracks are formed during cooling through the zirconia tetragonal-monoclinic transformation that occurs at $500-750{ }^{\circ} \mathrm{C}[7,33]$ as noted by cracks often observed around the monoclinic zirconia grains. During heating, the monoclinic-tetragonal transformation occurs at $970-1100{ }^{\circ} \mathrm{C}$. The induced volume expansion creates stress in the surrounding mullite matrix.

In our case, the obtained results seem to indicate a different behaviour with a global improvement in the thermal shock resistance of the composite often noted with the first temperature cycle.

It is likely that the presence of the zirconia grains improved the shock resistance owing to the deviation of cracks by zirconia grains. The results obtained from acoustic emission tests at 
high temperature allow us to better understand the mechanisms that occur in the microstructure when the temperature increases as well as the possible damage that may be generated. The results of the tests performed up to $1300{ }^{\circ} \mathrm{C}\left(5^{\circ} \mathrm{C} / \mathrm{s}\right.$ for heating and cooling stages) on samples without thermal shock and after three thermal shock cycles are presented in Fig. 23.

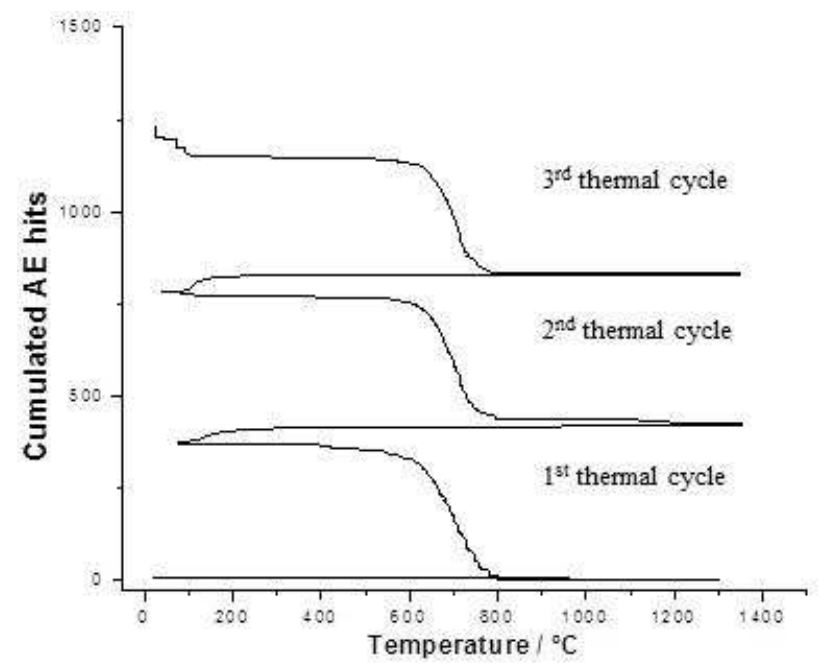

a)

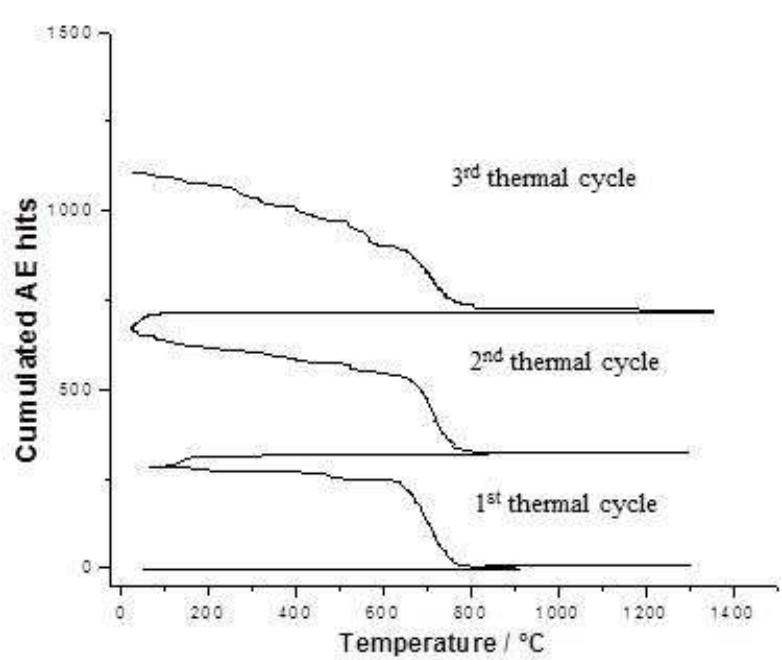

b)

Fig. 23. Cumulated acoustic emission (AE) hits versus temperature for three consecutive thermal cycles: a) sample not thermally shocked (NS) and b) sample after three thermal shocks (3TS).

These graphs present the evolution of the cumulated signals (measurements, i.e. "hits" which are standard $\mathrm{AE}$ denomination [12-15]) versus temperature during three successive thermal cycles. Two samples are compared, one without any applied thermal shock and one tested after three thermal shocks. The following three observations can be made:

1. The recorded AE activity occurs mainly during cooling for both samples (could be an indication of the onset of a common mechanism). The sudden rise in the cumulated hits is systematically noticed during the cooling stage at temperatures ranging from $800{ }^{\circ} \mathrm{C}$ to $600{ }^{\circ} \mathrm{C}$. This observation will be discussed next.

2. It is apparent that the global amount of recorded hits is higher for the non-shocked (NS) sample (over 1230) than that for the 3-times shocked (3TS) one (approximately 1100) 
3. Concerning this rapid augmentation of the number of cumulated hits, one can note that the evolution of the slope, cycle after cycle, is different for the non-shocked sample and the $3 \mathrm{TS}$ one. Indeed, the values of the slope seem to be rather equivalent for each cycle followed by non-AE activity for a range of temperatures (from $660{ }^{\circ} \mathrm{C}$ to room temperature) for the NS sample. Although this assumption could be considered for the first thermal cycle of the 3-times shocked sample, one can notice a very different evolution of the slope for cycles 2 and 3. For cycle 3, the AE activity appears to be continuous from $800{ }^{\circ} \mathrm{C}$ to room temperature. This evolution tends to demonstrate a different damage behaviour exhibited by the 3-times shocked sample compared to that of the non-shocked one.

A hypothesis is proposed to explain these different observations. As mentioned above, the transformation of tetragonal zirconia into monoclinic is generated during cooling at temperatures between $500{ }^{\circ} \mathrm{C}$ and $750{ }^{\circ} \mathrm{C}$. In this range, a very high percentage of $\mathrm{AE}$ activity occurs. A previous study carried out on refractories with a very high content of zirconia [15] has shown that this AE activity could be related in the early stage to the movement of the crystallographic variants present in the phases at the time of transformation. Patapy et al. [15] also showed that the transformation of zirconia from monoclinic to tetragonal phase (or the reverse), which has a volume expansion (or shrinkage) for specific temperatures, tends to generate significant cracking in the glassy phase at the interface with the dendrites of $\mathrm{ZrO}_{2}$. This explanation can satisfy the previous observations 1 and 2, assuming that for both samples, the early beginning of AE activity is a consequence of the motion of the variants inducing an internal state of stress in the material, leading to the microcracking of the glassy phase and self-producing a large and sudden release of energy.

Moreover, Ewais et al. [34] have observed in sintered zirconia mullite alumina composites that the cracks generated from the thermal shock test do not propagate and are stopped by zirconia grains and some pores. Rendtorff et al. [5] studied the thermal shock behaviour of a dense zirconia mullite composite, finding a decrease in the elastic modulus because of the creation of microcracks. After two thermal cycles, Young's modulus remains constant, indicating that the composite exhibited a high resistance to crack propagation. The dispersion of zirconia grains in the mullite matrix improves the thermomechanical properties because the zirconia transformation induces microcrack formations and residual stresses. The small cracks resulting from the transformation of zirconia interact with the thermal shocks cracks; therefore, the thermal shock resistance can be explained by three phenomena: 
- the deviation of thermal shock cracks by the zirconia grains

- the formation of microcracks around the zirconia grains

- $\quad$ the residual stresses

In the innovative zirconia-mullite raw material, sintered from an andalusite/alumina/zircon mix, most zirconia grains are monoclinic. High-temperature X-rays analysis shows that the transformation of the monoclinic $\mathrm{ZrO}_{2}$ phase (baddeleyite) into the tetragonal phase with increasing temperature is a reversible transformation (Fig. 24). The mineralogy is similar before and after the thermal shock. Therefore, as shown in the SEM micrographs of zirconia grains (Fig.25 a- initial state, b- after the first thermal shock), this transformation does not create modifications of the microstructure in and around the zirconia grains.

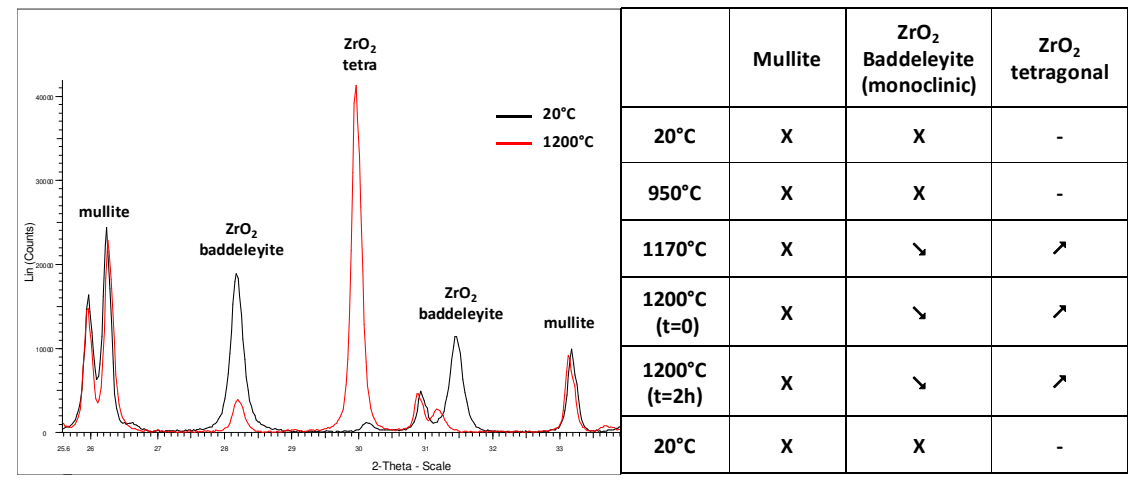

Fig. 24. Crystalline phases at $20{ }^{\circ} \mathrm{C}$ and at $1200{ }^{\circ} \mathrm{C}$ (XRD analysis)
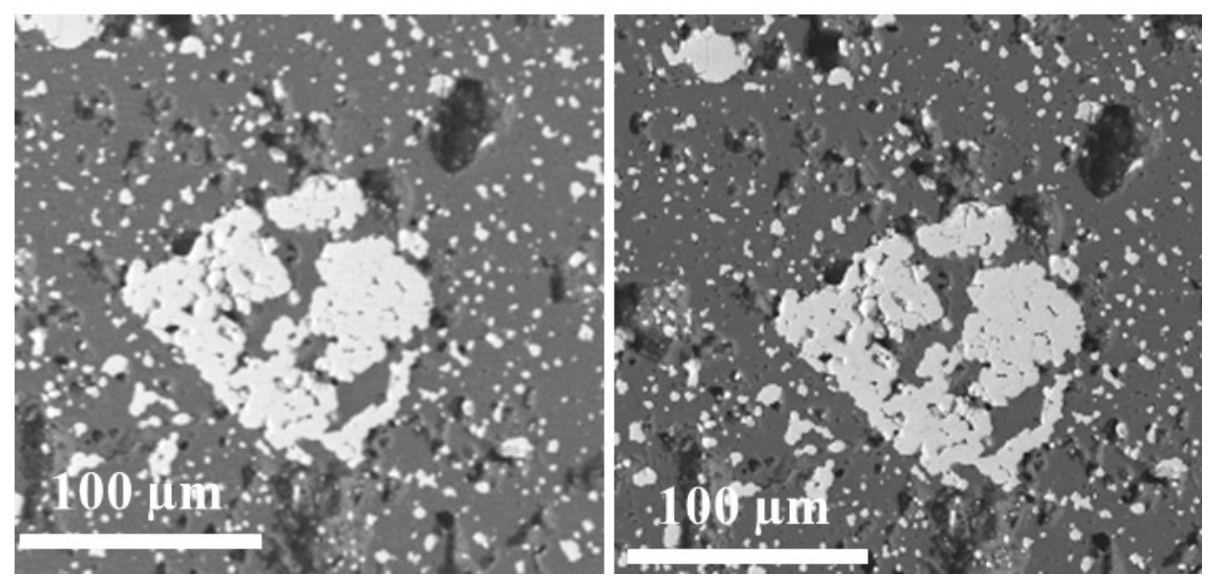

a) Initial state

b) After the first thermal shock

Fig. 25. Evolution of zirconia grains after a thermal shock at $1200{ }^{\circ} \mathrm{C}-20{ }^{\circ} \mathrm{C}$ (backscattered electron SEM micrographs)

It is likely that the presence of the zirconia grains improves the shock resistance owing to the deviation of cracks by zirconia grains. However, most likely, this is not the dominant 
phenomenon that would explain the slight increase in the ultrasonic velocity after the first thermal shock. This behaviour of the sintered zirconia mullite composite is caused by the presence of mullitized andalusite. Indeed, at high temperature, mullite can crystallize from the residual glassy phase, and this liquid glassy phase can repair the microcrack network. This hypothesis confirms observations 2 and 3 made for the 3-times shocked sample. Fig. 26 shows that the defect present in the initial state was partially repaired after the first thermal shock. Microcracks were deflected and stopped in the glassy zones, mullite had crystallized from the liquid phase and formed bridges which connect the edges of the cracks. This liquid phase is highly advantageous in terms of thermal shock resistance.

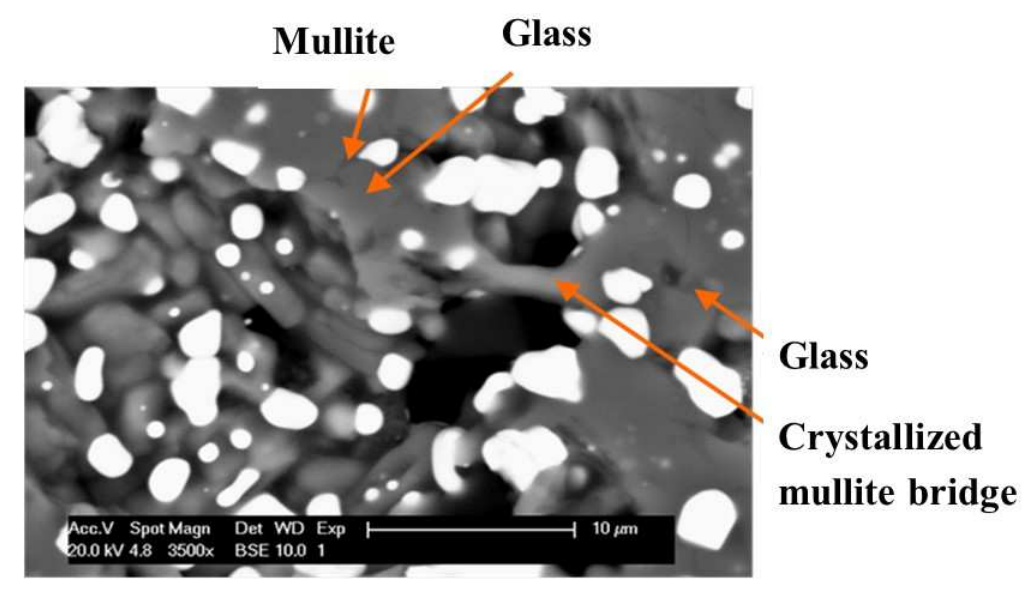

Fig. 26. Detail of the crack repairing process

(During the heating, the cracks generated by the prior thermal shock are partially repaired by a crystallized mullite bridge and by the glassy phase as shown in this figure)

\section{Conclusion}

An innovative zirconia mullite raw material was developed by a sintering process of andalusite, zircon and alumina fine powders. This sintered zirconia mullite raw material is composed of mullite $\left(2 \mathrm{SiO}_{2} .3 \mathrm{Al}_{2} \mathrm{O}_{3}, 74\right.$ wt.\%) zirconia $\left(\mathrm{ZrO}_{2}, 19\right.$ wt.\%) and silica-rich glass (7 wt.\%). The microstructure consists of fine zirconia particles in a mullite matrix and a residual glassy phase.

The material shows a very interesting behaviour when it is subjected to thermal shock.

Surprisingly, during the first thermal shock, the material appears to strengthen and is not damaged during the subsequent thermal cycling. This specific behaviour is obtained owing to the presence of the residual glassy phase and the microstructure of the mullitized andalusite. Furthermore, this material has good resistance to corrosion by alumina-lime slag or soda-lime glass. It is impregnated less by slag and glass than fused zirconia mullite. Moreover, the liquid 
phase is more viscous at high temperatures than either the fused zirconia mullite or the commercial sintered product.

Combining mullite and zirconia into a composite enhances the thermal shock resistance and the corrosion resistance against an alumina-lime slag and a soda-lime-silica glass. The combination of several mechanisms leads to the improved properties. The role of andalusite is predominant:

- It is the main source of mullite.

- The alkali in the andalusite accelerate the zircon decomposition

- A specific microstructure is obtained by decomposition to mullite and a glassy phase. At high temperature, this silica-rich glassy phase is viscous.

During thermal shock, the glassy phase could deflect and stop microcracks, and during further heating treatment, the liquid glassy phase repairs the cracks.

Zirconia grains also play an important role. The transformation of zirconia at high temperature creates microcracks and residual stresses that can deflect thermal shock cracks. Furthermore, since zirconia has a low solubility in glass and slag, zirconia grains could make a corrosion barrier in the impregnated zone.

The use of andalusite as a source of mullite is highly beneficial. Andalusite causes the decomposition of zircon at lower temperatures than $1600{ }^{\circ} \mathrm{C}$ and creates a specific microstructure of a mullite matrix with a residual glassy phase. During thermal shock, some microcracks are created, and during further heating treatment, the liquid glassy phase repairs the cracks. The transformation of zirconia creates microcracks and residual stresses that can deflect the thermal shock cracks.

All the hypothesis proposed to explain the occurrence of the microcracking mechanisms and the repairing process acting after several thermal shock cycles are validated by rigorous microstructural observations closely coupled to the acoustic emission technique, which allows a better understanding of the chronology of damage within the material.

This sintered zirconia mullite material appears to be promising for use as a raw material for refractory manufacture that will be subjected to thermal shocks and corrosion by slag or glass. This product could be an interesting alternative to replace alumina-chromium refractories, which have high costs and an unfavourably environmental impact. 


\section{References}

[1] H. Salmang, H. Scholze, Keramik, $7^{\text {th }}$ German Edition, edited by R. Telle, Springer, Berlin-Heideberg, 2007

[2] P. Boch, J.P. Giry, Preparation and properties of reaction-sintered mullite- $\mathrm{ZrO}_{2}$ ceramics, Mat. Sci. Eng., 71 (1985) 39-48

[3] F. Cambier, C. Baudin De La Lastra, P. Pilate, A. Leriche, Formation of microstructural defects in mullite-zirconia and mullite-alumina-zirconia composites obtained by reactionsintering of mixed powders, Br. Ceram. Trans. J., 83 (1984) 196-200

[4] E. Di Rupo, M.R. Anseau, Solid state reactions in the $\mathrm{ZrO}_{2}-\mathrm{SiO}_{2}-\alpha \mathrm{Al}_{2} \mathrm{O}_{3}$ system, J. Mater. Sci., 15 (1980) 114-118

[5] N. Rendtorff, L. Garrido, E. Aglietti, Mullite-zirconia-zircon composites: properties and thermal shock resistance, Ceram. Int., 35 (2009) 779-786

[6] N.M. Rendtorff, L.B. Garrido, E.F. Aglietti, Thermal shock behavior of dense mullitezirconia composites obtained by two processing routes, Ceram. Int., 34 (2008) 2017-2024

[7] M. Hamidouche, N. Bouaouadja, H. Osmani, R. Torrecillias, G. Fantozzi, Thermomechanical behaviour of mullite-zirconia composite, J. Eur. Ceram. Soc., 16 (1996) $441-445$

[8] N. Rendtorff, L. Garrido, E. Aglietti, Effect of the addition of mullite-zirconia to the thermal shock behavior of zircon materials, Mater. Sci. Eng., A, 498 (2008) 208-215

[9] C. F. Chan, Y. C. Ko, Effect of $\mathrm{Cr}_{2} \mathrm{O}_{3}$ on slag resistance of $\mathrm{Al}_{2} \mathrm{O}_{3}-\mathrm{SiO}_{2}$ refractories, J.Am.Ceram.Soc 75 [10] (1992) 2857-2861

[10] H. Majidian, L. Nikzard, H. Eslami-Shahed, T. Ebadzadeh, Phase evolution, microstructure and mechanical properties of alumina-mullite-zirconia composite prepared by Iranian andalusite, Int. J. Appl. Ceram. Technol., 13 [6] (2016) 1024-1032

[11] N.C. Biswas, S. Chaudhuri, Comparative study of zirconia-mullite and alumina-zirconia composites, Bull. Mater. Sci., 22 (1999) 37-47

[12] D. Bianchi, E. Mayrhofer, M. Gröschl, G. Betz, A. Vernes, Wavelet packet transform for detection of single events in acoustic emission signals. Mech. Syst. Signal Process. 441 (2015) 64-65

[13] L.H.A. Maia, A.M. Abrao, W.L. Vasconcelos, W.F. Sales, A.R. Machado, A new approach for detection of wear mechanisms and determination of tool life in turning using acoustic emission tribol. Int. 2015, 92 (2015) 519-532 
[14] A. Vinogradov, I.S. Yasnikov, On the nature of acoustic emission and internal friction during cyclic deformation of metals, Acta Mater. 70 (2014) 8-18

[15] C. Patapy, A. Proust, D. Marlot, M. Huger, T. Chotard, Characterization by acoustic emission pattern recognition of microstructure evolution in a fused-cast refractory during high temperature cycling, J. Eur. Ceram. Soc, 30 [15] (2010) 3093-3101

[16] H. Schneider, A. Majdic, Kinetics and Mechanism of the Solid State High Temperature Transformation of Andalusite $\left(\mathrm{Al}_{2} \mathrm{SiO}_{5}\right)$ into $3 / 2$ Mullite $\left(3 \mathrm{Al}_{2} \mathrm{O}_{3} \cdot 2 \mathrm{SiO}_{2}\right)$ and Silica $\left(\mathrm{SiO}_{2}\right)$, Ceramurgica International, 5 (1979) 31-36

[17] JP. Ildefonse, V. Gabis, F. Cesbron, Mullitization of andalusite in refractory bricks , Key Engineering Materials, Trans Tech Publications, 132-136 (1997) 1798-1801

[18] JP. Ildefonse, V. Gabis, M. Rigaud, L. Rebouillat, P. Daniellou, P. Dubreuil, Mullitization of andalusite in bricks and castables, Proceedings Unified Intern. Techn. Conf. on Refractories, The American Ceramic Society, Westerville, 2 (1997) 899-908

[19] W. Pannhorts, H. Schneider, The high-temperature transformation of andalusite $\left(\mathrm{Al}_{2} \mathrm{SiO}_{5}\right)$ into $3 / 2$ mullite $\left(3 \mathrm{Al}_{2} \mathrm{O}_{3} 2 \mathrm{SiO}_{2}\right)$ and vitreous silica $\left(\mathrm{SiO}_{2}\right)$, Mineralogical Magazine, 42 (1978) 195-198

[20] A. Hülsmann, M. Schmücker, W. Mader, H. Schneider, The transformation of andalusite to mullite and silica: Part I. Transformation mechanism in [001] $]_{\mathrm{A}}$ direction, American Mineralogist, 85 (2000) 980-986

[21] A. Hülsmann, M. Schmücker, W. Mader, H. Schneider, The transformation of andalusite to mullite and silica: Part II. Transformation mechanisms in $[100]_{\mathrm{A}}$ and $[010]_{\mathrm{A}}$ directions, American Mineralogist, 85 (2000) 987-992

[22] J. Poirier, M. L. Bouchetou, L. Colombel, P. Hubert, Andalusite : an attractive raw material for its excellent thermal shock resistance, Refractories World Forum 1 (2009) 93-102 [23] M.L. Bouchetou, J.P. Ildefonse, J. Poirier, P. Daniellou, Mullite grown from fired andalusite grains: the role of impurities and of the high temperature on the kinetics of mullitization and consequences on thermal shocks resistance, Ceram. Int., 31 (2005) 9991005 .

[24] M. L. Bouchetou, J. P. Ildefonse, J. P., Production of high mullite material from natural andalusite: influence of grain size, Refractories Applications and News, 1 [5] (2005) 16-21

[25] A. Kaiser, M. Lobert, R. Telle, Thermal stability of zircon $\left(\mathrm{ZrSiO}_{4}\right)$, J. Eur. Ceram. Soc. 28 (2008) 2199-2211

[26] M.R. Anseau, J.P. Biloque, P. Fierens, Somme studies on the thermal stability of zircon, J.Mater.Sci., 11 [3] (1976) 578-582 
[27] R. Klute, Phasenbeziehungen im System $\mathrm{Al}_{2} \mathrm{O}_{3}-\mathrm{Cr}_{2} \mathrm{O}_{3}-\mathrm{ZrO}_{2}-\mathrm{SiO}_{2}$ unter besonderer Berücksichtigung des korundhaltigen Bereiches, Diplomarbeit RWTH Aachen Germany, Lehrstuhl für technische Mineralogie (Chair of applied Mineralogy), Supervisor: E.Woermann, 1982

[28] H. Pooladvand, B. Mirhadi, S. Baghshahi, A.R. Souri, K. Arzani, Effects of alumina and zirconia addition on transformation of andalusite to mullite, Adv.Appl.Ceram., 108 [7] (2009) 389-395

[29] C. Aksel, The microstructural features of an alumina-mullite-zirconia refractory material corroded by molten slag, Ceram. Int. 29 (2003) 305-309

[30] T.Asokan, Microstructural features of fusion cast $\mathrm{Al}_{2} \mathrm{O}_{3}-\mathrm{ZrO}_{2}-\mathrm{SiO}_{2}$ refractories, J.Mater.Sci.Lett, 13 (1994) 343-345

[31] P. Prigent, M.L. Bouchetou, J. Poirier, Andalusite: an amazing refractory raw material with excellent corrosion resistance to sodium vapours, Ceram. Int., 37 (2011)2287-2296 [32] G. Urbain, F. Cambier, M. Deletter, MR. Anseau, Viscosity of Silica Melts, Trans. J. Br. Ceram. Society, 80 (1981) 139-141

[33] N. Claussen, J. Jahn, Mechanical properties of sintered, in situ-reacted mullite-zirconia composites, J.Am.Ceram.Soc. 63 (1980) 228-229.

[34] E.M.M. Ewais, D. Hussien Amin Besisa, Z. Ismail Zaki, A. El Hakim Taha Kandil, Tailoring of functionally graded zirconia-mullite/alumina ceramics, J. Eur. Ceram. Soc. 32 (2012) 1561-1573 